AÜIFD Cilt XLIV (2003) Sayı I s. 187-226

\title{
Kurtuluş Savaşı Döneminde Medrese Öğretim Programları ve Ders İçeriklerinin Düzenlenmesi Çalışmaları
}

\section{Zeki Salih ZENGIN}

Yrd. Doç. Dr., Çukurova Üniversitesi İlahiyat Fakültesi

e-mail: zsalihcu.edu.tr

Abstract: Activities For the Formation of the Contents of the Lessons and Curriculums at Madrasas During the Independence War and Religious Education. Reformation activities for madrasas started in 1914 and continued until 1923. According to the Medâris-i Ilmiye Nizamnamesi that prepared in 1921, had been established two madrasas : Dârü'l-Hilâfe and Ilmiye Madrasas. The aim of Ilmiye madrasas were only to educate religious officials. On the other hand the aim of Dârü'l-Hilâfeti'l-Aliyye Madrasas were to educate superior religious officials and teachers who would be employed in primitive and secondary schools. In this article, contents of the lessons, cirriculums and the reason for the placing any lesson into the schedule are examined.

Key Words: Religious Education, Madrasa, Primary School, Secondary School.

\section{Giriş}

Osmanlı medreselerinin II. Meşrutiyet yıllarından itibaren eğitim alanındaki yeni gelişmelere paralel olarak ıslahına çalışıldığı ve bu amaçla idarî teşkilattan öğretim programlarına kadar uzanan konularda ciddî 
çalışmaların yapıldığı bilinmektedir'. Yapılan bu çalışmalar, elde edilen uygulama sonuçlarına göre yenilenerek dönem boyunca, hatta Millî Mücadele dönemini de kapsayan süreçte devam ettirilmiştir. Medreseler için oldukça önemli sayılması gereken bu süreç içinde burada ele alacağımız konu, Millî Mücadele döneminde medreselerde uygulanmak üzere hazırlanan medrese öğretim programlarının hazırlanması, din eğitimi kapsamına giren derslere verilen yer ile bu derslerin içeriklerinin düzenlenmesi çalışmalarının tespit ve değerlendirilmesi olacaktır. Çalışmamızda medreselerin, örgün ve yaygın din eğitimi alanlarında istihdam edilecek görevlilerin yetiştirilmesinde üstlendikleri amaç ve sorumluluklarını, öğretim programlarının hazırlanması noktasında ne derecede yerine getirebildikleri sorusuna cevap arayacağız. Çalışmanın, geçmişe mâl olmuş bir konunun aydınlatılması yanında günümüzde aynı amacı taşıyan kurumlar için de yapılacak program geliştirme çalışmaları için karşılaştırma ve değerlendirme imkânı sunacağını umuyoruz.

Eğitim, öğretim ve ders programı kavramları eğitimciler tarafından sıkça, kimi zaman da birbirlerinin yerine kullanılan kavramlardır. Bunlar arasında en kapsamlısı olan eğitim programı kavramı, bir eğitim kurumunun hem genel, hem de özel amaçlarının gerçekleşmesine yönelik ders içi ve dışı bütün faaliyetlerini kapsar. Ögretim programı ise eğitim programı içinde yer verilen belirli bilgi kategorilerinden oluşan, bir kısım okullarda beceriye ve uygulamaya ağırlık tanıyan, bilgi ve becerinin eğitim programının amaçları doğrultusunda planlı bir biçimde kazandırılmasına dönük programdır. Ders programı da öğretim programlarında yer alan bilgi kategorilerinin ve faaliyet alanlarının, eğitim amaçları ile ilişkili olan özel amaçlarını gerçekleştirmeleri için öğretim ilkelerini, konuların alt kategorilerini, değerlendirme esaslarını içeren, eğitim ve öğretim programlarındaki esasları davranışa dönüştüren programdir ${ }^{2}$. Buna göre her üç program da belirlenen amaçlara ulaşma hususunda genelden özele doğru bir daralma, buna karşılık aynı zamanda hedeflere ulaşma açısından müstakil bir öğretim alanında yoğunlaşma niteliği taşımaktadır.

Bir eğitim-öğretim sistemi içerisinde yer alan kurumların açılması, okutulacak derslerin ve bu dersler içerisinde hangi konulara yer verileceğinin belirlenmesi, eğitimde amaçlar konusu ile iç içedir. Buna göre, bir eğitim sisteminin genel amaçları belirlendikten sonra sistemin içinde yer alan kurumların bütün faaliyetlerinin de bu amaçları gerçekleştirebilecek biçimde

' II. Meşrutiyet döneminde gerçekleştirilen medrese 1 slahat girişimleri için, Bk. Nesimi Yazıcı, "Osmanlılann Son Döneminde Din Görevlisi Yetiştirme Çabaları Üzerine Bazı Gözlemler", Diyanet Dergisi, XXVII, Sayı : 4, Ankara 1991, s. 55-123; Z. Salih Zengin, II. Meşrutiyette Medreseler ve Din Eğitimi (1908-1918), Akçağ Yay., Ankara 2002.

2 Fatma Varış, Eğitimde Program Gelił̧tirme Teori ve Teknikler, AÜEF Yay., Ankara 1988, s. 18. Ayrıca, Bk. Ruşen Alaylıơlu/Ferhan Oğuzkan, Ansiklopedik Eğitim Sözlüğü, Istanbul 1968, s. 282. 
düzenlenmeleri gerekir ${ }^{3}$. Dolayısıyla bir eğitim kurumunda okutulması kararlaştırlan bütün dersler ile içeriklerinin kendi içlerinde bütünlük ve uyumu sağlamaları gerektiği gibi, belirlenen genel amaçların gerçekleşmesine de hizmet etmesi gerekir.

İslâm dünyasında ve özellikle Osmanlılarda, bugünkü anlamda orta ve yüksek dereceli örgün eğitimin neredeyse tamamı medreselerde gerçekleştirilmektedir. Günümüzde olduğu gibi ayrıntılı ve yazılı olarak belirtilmemesine rağmen medreselerin eğitim-öğretim açısından belirli amaçlar taşımadıklarını ileri sürmek mümkün değildir. Klasik dönem medreselerinin kuruluş amaçlarını bazı belgelerin yanısıra, uygulanan programlar ve mezunların istihdam alanlarına bakarak belirlemek mümkündür. Medreselerin din hizmetlerinin yanında özellikle hukuk ve tıp alanlarında ihtiyaç duyulan elemanların yetiştirilmesini hedeflediği, ayrıca toplumda ihtiyaç duyulan ve yüksek ögrenimi gerektiren diğer meslek erbabının da yetiştiği genel ögretim kurumları olduğunu ileri sürmek mümkündür ${ }^{4}$. Başta Arapça olmak üzere Kelam, Tefsir, Hadis ve İslâm Hukuku gibi din bilimlerinin yanında Fen ve Matematik öğretimine yer verilen öğretim programları, medreselerin bu amaçlarını yerine getirebilecek niteliktedir. Diğer taraftan, amacın sadece belirli hizmetleri yerine getirecek meslek erbabı yetiştirmekten ibaret tutulmaksızın aynı zamanda dinî anlamda iyi bir insan ve vatandaş yetiştirmek gibi - her eğitim sistemi için içeriği farklı da olsa - hedeflerin göz önünde tutuldugunu ileri sürmek de yanlış olmasa gerektir.

Geleneksel medrese öğretim programlarında yer alan derslerin içeriklerinin düzenlenmesi konusunda müstakil çalışmaların varlığı hakkında bilgimiz bulunmamaktadır. Bu dönemde programlarda yer verilen ögretim, derslerin, okutulan kitapların adı ile anıldığına bakılırsa, içeriği de bu kitapların oluşturduğunu iddia etmek yanlış olmayacaktır.

Asıl konumuza geçmeden önce Tanzimat sonrası Osmanlı egitim sistemi ve medreselerin durumu hakkında kısa bilgi vermeyi uygun görüyoruz.

3 Varış, Eğitimde Program Geliştirme Teori ve Teknikler, s. 128 vd.

4 Krş. Emin Bey, "Tarihçe-i Tarîk-i Tedris", Ilmiye Salnamesi, Matbaa-i Âmire, İstanbul 1334, s. 645; Fahri Unan, Kuruluşundan Günümüze Fatih Külliyesi, Yayınlanmamış Doktora Tezi, HÜSBE, Ankara 1993, s. 7-9, 354-360; Fahri Unan, "Osmanlı IImiye Tarîkinde Pâyeli Tayinler Yahut Devlettc Kazanç Kapısı”, Belleten LXII, Sayı : 233, Nisan 1998, s. 53 vd.; Mehmet İpşirli, "Osmanlı Devleti'nde Kazaskerlik (XVII. yüzyıla kadar)", Belleten LXI, Sayı : 232, Aralık 1997, s. 603-605; Mehmet Ipşirli, "XIX. Yüzyılda Osmanlı İlmiye Mesleği ve Uleması Hakkında Gözlemler", Tanzimat'ın 150. Yıldönümü Uluslararast Sempozyumu (Bildiriler), Ankara 1991, s. 215; Cahid Baltacı, XV.- XVI. Asırlarda Osmanlı Medreseleri, İrfan Matbaası, İstanbul 1976, s. 19, 56-58; F. Reşit Unat, Türkiye Eğitim Sisteminin Gelişmesine Tarihî Bir Bakış, MEB Yay., Ankara 1964, s. 4. 
Tanzimat dönemi, Osmanlı Devleti'nin gerileme döneminden itibaren içine düştüğü askerî, siyasî ve ekonomik bunalımlara çözüm bulma çabalarının önemli bir dönüm noktası olmuştur. Önceleri daha çok asken̂́ alanla sınırlı kalan çözüm arayışlarının, daha sonra Batılılaşma, çağdaşlaşma veya modernleşme şeklinde idare, ekonomi, hukuk ve nihayet eğitim alanlarına doğru genişleyerek günümüze kadar uzanan millî bir hedef hâline geldiği bilinmektedir. Belirlenen hedeflere varılabilmesinin, başlatılan değişim sürecini devam ettirecek insanların yetiştirilmesine bağlı olduğu, bunun da eğitimdeki amaç ve hedeflerin değişmesi anlamına geleceği açıktır. Değişimi gerçekleştirecek eğitim sisteminin oluşturulmasında Tanzimatçıların iki seçeneği bulunmaktadır: Geleneksel eğitim kurumları olan medreselerin ıslah edilmesi ya da bunların bir yana bırakılarak yeni bir sistemin kurulması. Bunlardan ikincisi tercih edilerek medreseler kendi hâline bırakılmıştır.

Biz burada böyle bir hareket tarzının gerekliliği ya da doğruluğu meselesini tartışacak değiliz; anciak şurası da muhakkaktır ki gelişmelerin medreselerin etkinlik alanlarında doğurduğu değişim, öğretim amaçlarında ve bu amaçları gerçekleştirmek üzere teşkilat ve programlarında da değişikliğe gidilmesi sonucu zorunlu olarak ortaya çıkmıştır ${ }^{5}$. Buna göre medreseler için ilki hukuk, ikincisi yaygın ve örgün din eğitimi ile ilgili iki faaliyet alanı bulunmaktadır. Tanzimat'tan itibaren özel hukuk dışındaki alanlarda Batı hukuku esas alınarak yeni düzenlemelerin yapılması sonucunda, İslâm hukukunun geçerli olduğu müslüman teb'arın özel hukuka ait davalarının görüldüğü şer'î mahkemelerde görev alacak hâkimlerin (kadılar) yetiştirilmesi meselesi ele alınarak 1854 yılında Medrese-i Nüvvab açılmıştır ${ }^{6}$. Medreselere kalan iki faaliyet alanından hukuk ile ilgili olarak, oldukça erken bir tarihte yeni şartiara uygun düzenlemeler başlamış olmakla birlikte, din eğitimi ve öğretimi ile ilgili olarak hem müftü, vâiz ve imamhatip gibi yaygın; hem de mektep ve medreselerdeki örgün din eğitimi ve öğretiminin yeniden düzenlenmesi çalışmalanının gerçekleştirilmesi ancak II. Meşrutiyet döneminde mümkün olabilmiştir.

II. Meşrutiyet döneminde medreselerin ıslahı için ilk teşebbüs 1910 yılında yapılmakla birlikte asıl ve ciddî olanı 1914 yılında Islâh-ı Medâris Nizamnamesi'nin hazırlanmasından sonraki dönemde gerçekleştirilmiştir.

5 Tanzimat yıllarında özcllikle hukuk ve idare alanlanındaki gelişmeler medreselerin etkinlik alanlarının daralmasına neden olmustur. Krş. Nesimi Yazıcı, "Osmanlı Son Dönemi Medreselerinde Fen Bilimlerinin Tedrisatı Konusunda Bazı Düşünceler", AÜIF Dergisi XXXVIII, Ankara 1998, s. 111-112.

- Daha sonra II. Abdülhamit devrinde Mekteb-i Nüvvâb adını alan ve II. Meşrutiyet'te Medresetü'l Kuzât adı ile yeniden düzenlenen bu kurum için, Bk. 1. Hakkı Uzunçarşılı, Osmanl Devleti'nin Ilmiye Teşkilatı, TTK Yay., Ankara 1988, s. 268; O. Nuri Ergin, Türk Maarif Tarihi I-II, Eser Matbaası, İstanbul 1977, s. 157-159; Medresetü'l-Kuzât Nizamname ve Tâlimatnamesi, Matbaa-i Âmire, İstanbul 1332. 
İstanbul'da kurulan Dârü'l-Hilâfeti'l-Aliyye Medresesi ıslahat planının uyguland $\breve{g}_{1}$ örnek medrese tipi olarak belirlenerek genel olarak orta, yüksek ve ihtisas öğretim kademelerine ayrılmış ve her biri için ayrı programlar hazırlanmıştır. Bu çalışmalarla, modern eğitim kurumlarında yapılanma örnek alınarak orta dereceli medreselerdeki öğretim yüksek din öğretimine hazırlık, yüksek dereceli medrese ve ihtisas medresesi ise tamamen özel alana yönelerek din bilimlerinde uzmanlar yetiştirmek amacını taşımaktadır. Nitekim, medreselerdeki ögretim kademeleri için 1914 yılından 1923 yılındaki son düzenlemeye kadar hazırlanan programlara bakıldığında orta öğretimin ilk iki kademesinde mesleğe hazırlığın yanında genel öğretime ağırlık verildiğgi, yüksek ögrretim ve ihtisas ögretimi kademelerinde ise tamamen meslekî öğretim amacının taşındığı göruilmektedir. Diğer taraftan yine bu dönemde amacı sadece imam-hatip, müezzin ve vaiz gibi din görevlisi yetiştirmek olan müstakil medreselerin açılması da gerçekleştirilmiştir.

1914 ve sonrasındaki çalışmalara neden olan temel amaçların neler olduğu hakkında bilgiler bulmak mümkündür. Nitekim 1914 tarihli Islâh-ı Medâris Nizamnamesi'nin hazırlanı̧ gerekçesinde (esbâb-ı mûcibe lâyihası), medreselerin içine düştükleri yetersizliklere işaretle yeni gelişmelere göre yeniden düzenlenmelerine duyulan ihtiyaçtan bahsedilmekte ve nizamnamenin, medreselerin "terakkiyât ve tekemmülâtına medâr olabilecek bazı esâsâtı muhtevî ve mütâlaât ve mülâhazât-ı âtiyeye mübtenî olmak üzere" hazırlandığı belirtilmektedir. Ardından da bu çerçevede yapılması planlanan işlerden bahsedilerek, programlar hazırlanırken talebelerin, kendilerinden beklenen hizmet alanının kapsamı ve temsil edecekleri mevkiin gereği olarak din ilimlerinin (ulûm-1 şer'iye) yanısıra bunların dışındaki ilimlerden (fünûn-1 lâzıme) haberdar olmaları için bu derslerin de ilave edildiği belirtilmektedir ${ }^{7}$. Bu ifadelerden, düzenlemenin amacının hem meslek hem de genel kültür olarak nitelendirebileceğimiz ve o döneme kadar medrese programlarında yer almayan Türkçe, yabancı dil, beden eğitimi vs. gibi öğretim alanlarına yer verilerek din görevlilerinin çağdaş bilgilere sahip olarak yetiştirilmesi olduğu anlaşılmaktadır.

Ögretim programları da dâhil ıslahatın gerçekleştirilmesindeki önemli amaçlardan diğeri de medreselerin mevcut eğitim sistemine uyum sağlama arzusudur. Medreselerin orta, yüksek ve ihtisas derecelerine ayrılması yanında özellikle orta kısım medrese programlarında kültür derslerine yoğun olarak yer verilmesi bunu açıkça göstermektedir ${ }^{8}$.

7 "Islâh-ı Medâris Nizamnamesi'nin Esbâb-1 Mûcibe Lâyihası", Ilmiye Salnamesi, Matbaa-i Âmire, Ístanbul 1334, s. 652, 654.

8 Zengin, II. Meşrutiyet'te Medreseler ve Din Eğitimi, s. 107-133. 


\section{TBMM Tarafından Medrıseler İçin Hazırlanan Ders Program- ları ve İçerikleri}

1921 yilında TBMM tarafından hazırlanan ve Ankara Hükümeti'nin kontrolü altındaki bölgelerdeki medreselerin ıslahını hedefleyen Medâris-i İlmiye Nizamnamesi'nde İlmiye ve Dârü'l-Hilâfe adlarıyla iki tür medreseden söz edilmektedir. 1914 yılındaki ıslah çalışmalarının ürünü olan Dârü'l-Hilâfe Medreseleri, aradan ggeçen zaman içerisinde İstanbul ile sınırlı kalarak taşrada yeterince yaygınlaştırılamamıştır. Bu durumda Dârü'l-Hilâfe teşkilatına giremeyen birçok medrese bulunmaktadır. İşte 1921 yılında Ankara'da hazırlanan Medâris-i Ilmiye Nizamnamesi'nin asıl amacı; Dârü'lHilâfe teşkilatı içine giremeyen İlmiye Medreselerinin, başka bir teşkilat altında toplanarak verimli hâle getirilmesidir. Nizamname hükümlerine göre idaresi planlanan bu medreseler için ayrı bir program hazırlanmakla birlikte, yer verilen derslerin içerikleri hakkında bilgi bulunmamaktadır 9

Burada ele alacağımız konu, bu medreseler için hazırlanan programların din eğitimi açısından incelenmesinin yanısıra programda yer alan din ögretimi ile ilgili derslerin içeriklerinin tanıtılmasıdır. Bu çerçevede, programları hakkında bilgi bulunan medreseleri ayrı başlıklar altında ele alıp, önce genel özellikleri ile tanıtarak daha sonra ögretim basamaklarına göre ders programlarını ve ders içeriklerini incelemeyi uygun görüyoruz.

\section{A. Dârü'l-Hilâfe Medreseleri.}

Dârü'l-Hilâfe Medreselerinin kuruluşunun 1914 yılına kadar uzandığı ve medreselerin kapatıldığı döneme kadar çeşitli zaman aralıkları içinde, uygulamaların sonuçları da dikkate alınarak, teşkilat ve programlarının yeniden gözden geçirildiğinden bahsetmiştik. Dârü'l-Hilâfe Medreseleri mevcut yapıları itibarıyla geleneksel eğitimin temsilcisi konumundaki medreselerin, eğitimdeki modernleşmeye ayak uydurma çabalarının somut örneğini oluşturmaktadır. Nitekim 1921 yılında Medâris-i Ilmiye Nizamnamesi hazırlanırken bu medreselerin teşkilat ve idaresi ile ilgili herhangi bir kayıt getirilmeyerek daha önceki yapıları korunmuştur ${ }^{10}$. Yine bu medreseler için hazırlanan tâlimat da büyük ölçüde 1917 yılında belirlenen esasları içermektedir ${ }^{11}$. Bununla birlikte Dârü'l-Hilâfe Medreseleri'nin öğretim programlarının 1914 yılından itibaren süregelen geliştirilmesi geleneği, Ankara Hükümeti zamanında da devam ettirilmiş ve 1923 yılında bu medreselerin programı, ders içerikleri ile beraber yeniden

9 "Medâris-i İlmiye Nizamnamesi", mad. 24.

10 "Mcdâris-i İlmiye Nizamnamesi", mad. 1.

" 1922 yılında hazırlanan bu Tâlimat için, Bk. "Dârü'l-Hilâfeti'l-Aliyye Medâris Tâlimatnamesi”, Medâris-i Ilmiye Nizamnamesi, Şehzadcbaşı Evkâf-ı İslamiye Matbaası, 1338-1341, s. 16-37. 
düzenlenmiştir ${ }^{\prime 2}$. Çalışmamızdaki amacımız esas itibarıyla 1923 yılındaki program ve içerik çalışmasını incelemek olmakla birlikte, karşılaştırma imkânının yanında doğru ve tutarlı değerlendirme sağlaması düşüncesiyle 1922 yılında yine bu medreseler için İstanbul'da yapılan çalışmalarda belirlenen programlara ${ }^{13}$ da yer vermeyi uygun gördük.

Tesbit edebildiğimiz kadarıyla, birbirinin devamı ya da geliştirilmiş biçimi olarak kabul edilmesi gereken bu iki programdan 1922 yilında hazırlananı İstanbul'da, 1923 yılında hazırlananı ise Ankara'da, bu medreseler için yapılan son çalışmalardır. 1923 yılında Ankara'da yapılan çalışmanın baş tarafında yapılan açıklamada, Şer'iye Vekâleti'nde toplanan bir encümen tarafından hazırlanarak Vekâlet tarafından kabul edilen programın, medreselerdeki eğitim ve öğretimde kronikleşen bazı problemlere çözüm bulmayı amaçladığı ifade edilmektedir. Bu programda ayrıca ders içeriklerine de yer verilmektedir.

1914 yılından itibaren faaliyete geçen Dârü'l-Hilâfe Medresesi'nin kuruluş amaçları hakkında, özellikle bu yıl hazırlanan Islâh-ı Medâris Nizamnamesi'ni esas alarak bilgiler vermiştik. Kurtuluş Savaşı yıllarında bu amaçlarda herhangi bir değişikliğin olmadığı anlaşılmaktadır. Nitekim Dârü’l-Hilâfe Medresesi için 1922 yılında hazırlanan tâlimatta, mezunlar için öngörülen istihdam alanlarına bakıldığında, medresenin temel amacının din hizmetlerinin devamını sağlayacak imam-hatip, vaiz, müftü gibi görevlilerin yetiştirilmesi yanında mekteplerdeki Ulûm-1 Diniye derslerini okutacak, medreselerdeki öğretimin devamını sağlayacak idareci, muallim ve müderrislerin yetiştirilmesi olduğu da açıç̧a ifade edilmektedir. Tâlimata göre İptidâ-y1 Hâriç'i bitirenler köy camilerinin imam-hatiplikleri ile muallimlik görevlerine, İptidâ-yı Dâhil'i bitirenler şehir camilerinin imamhatiplikleri ile iptidai ve numûne mekteplerinin Ulûm-1 Diniye derslerinin muallimlik ve hâfız-ı kütüplük (kütüphane memuru) görevlerine, Sahn'ı bitirenler Meşîhat, Evkâf ve müftülüklerde memuriyet, tabur imamlı̆̆ı, Iptidâ-yı Hâriç ve Dâhil medreselerinde idareci ve muallimlik ile diğer medreselerde müderrislik görevlerine, Medresetü'l Mütehassısîn'i bitirenler ise Dârü'l-Hilâfe medreselerinde idareci ve muallimlik, müftülük, mekteplerdeki Ulûm-1 Diniye dersleri muallimliklerine, kürsü şeyhliği, alay ve sefâret imâmeti ${ }^{14}$ görevlerinin yanısıra bunlara denk diğer görevlere de atanabileceklerdir ${ }^{15}$.

12 Dârü'l-Hilâfe Medreseleri Ders Cetvelleri ve Müfredat Programı, Ögüt Matbaası, Ankara 30 Rcbiulevvel 1342-10 Teşrinisâni 1339.

${ }^{13}$ Dârü'l-Hilâfeti'l-Aliyye Medresesi Medresetü'l Kuzât Nizamnamesi, Şehzadebaşı Evkâf-1 Islamiye Matbaası. 1338-1340.

${ }^{14}$ Kürsü şeyhi, Cumhuriyet'ten önce Arapça okunan Cuma hutbesini anlamayan halka vaaz eden görevliye verilen addır. Cuma vaizi de denilmektedir. Bk. O. Zeki Pakalın. Osmanlı Tarih Deyimleri ve Terimleri Sözlüğü II, MEB Yay., İstanbul 1983, s. 345. Alay imamı ise askerî birliklerde alayın 1. taburunun imamına verilen addır. Alay ve tabur imamları görev 
Programlar hazırlanırken bu görevlilerin vazifelerini en iyi biçimde yapacak şekilde yetiştirilmelerinin göz önüne alındı̆̆ı görülmektedir. Mesela, 1923 yılında hazırlanan programa Türkçe derslerinin daha yoğun olarak konulmasının amacının; medresede öğrenim görenlerin dinini, mesleğini, milletini yanlış düşünce ve fikir akımlarına karşı savunabilmeleri için kendi dillerini yazılı ve sözlü olarak en iyi biçimde kullanabilmelerinin sağlanması olduğu vurgulanmaktadır. Benzer şekilde, medresenin yüksek ögretim kısmına Terbiye ve Içtima' (Eğitim ve Sosyoloji) derslerinin konulmasının nedeni, buradan mezun olacakların muallimlik görevine atanacak olmalarıdır ${ }^{16}$. Bütün burılar, program hazırlanırken belirlenen amaçların gerçekleştirilebilmesinin göz önünde tutulduğunu göstermektedir.

\section{Hazırlık Sinıfı}

TABLO 1 : 1922 Yılında DHA Medresesi İłzâri (Hazırlık) Sınıflan İçin Hazırlanan Program

\begin{tabular}{|c|c|c|c|}
\hline DERSLER & 1. Sinif & 2. $\operatorname{Sinif}$ & 3. Sinif \\
\hline$\overline{\text { Kur' } \underline{\underline{a} n-\ell} \text { Kerim }}$ & 4 & 4 & 4 \\
\hline Ilmihal & 3 & 3 & 2 \\
\hline Tarih-i İslâm & 2 & 2 & 2 \\
\hline Arapça & 5 & 5 & 5 \\
\hline Türkf̧c & 4 & 4 & 4 \\
\hline Hesap & 2 & 2 & 2 \\
\hline Coğrafya & 2 & 2 & 2 \\
\hline Hendese & - & - & 1 \\
\hline Hüsn-i Hat & 1 & 1 & 1 \\
\hline Toplam Saat & 23 & 23 & 23 \\
\hline
\end{tabular}

yaptıkları birliklerde aynı zamanda askırlere Türkçe okuma-yazma, hesap ve din bilgilerini öğretmekle de görevlidir. Bk. . O. Ze:ki Pakalın, Osmanlı Tarih Deyimleri ve Terimleri Sözlüğu I, MEB Yay., Istanbul 1971, s. 45; "Alay ve Tabur Imamlarının Vezâif-i Tedrisiyeleri Hakkında Nizamname". 4 Cemaziyelevvel 1332/18 Mart 1330 (31 Mart 1914), Düstur VI, II. Tertib, s. 332. Sefaret imamı ise yurt dışındaki elçiliklerde görevlendirilen din görevlisi olmalıdır.

is "Dârü"l-Hilâfeti'l-Aliyye Medâris Tâlimatnamesi", s. 36-37.

16 Dârü'l-Hilâfe Medreseleri Ders Cetvelleri ve Müfredat Programi, s. 7. 
TABLO 2 : 1923 Yılında Dârü'l-Hilâfe Medreseleri Hazırlık Sınıfları İçin Hazırlanan Program

\begin{tabular}{|c|c|c|}
\hline DERSLER & 1. $S_{\text {In } 1 \text { f }}$ & 2. Sinif \\
\hline Kur’ân-ı Kerim & 6 & $\overline{6}$ \\
\hline Müsâhabât-ı Diniye ve Ahlâkiye & 3 & 3 \\
\hline Tarih ve Siyer Musâhabeleri ${ }^{17}$ & 2 & 1 \\
\hline İlâhî̀ & 1 & 1 \\
\hline Türkçe & 6 & 5 \\
\hline Arabî & 5 & 6 \\
\hline Hesap & 4 & 2 \\
\hline Mâlûmât-1 Hendese ve Resm-i Hattî & - & 1 \\
\hline Coğrafya & 1 & 1 \\
\hline Mâlûmât-ı Sıhhiyc & - & 1 \\
\hline Hüsn-i Hat & 2 & 2 \\
\hline Lügat-ı Fârisî & - & 1 \\
\hline Muhâzarât & Ders haricinde & \\
\hline Terbiye-i Bedeniye & Ders haricinde & \\
\hline Toplam Saat & 30 & 30 \\
\hline
\end{tabular}

Dârü'l-Hilâfe Medreseleri'nin hazırlık sınıfları için 1922 ve 1923 yıllarında hazırlanan iki program karşılaştırıldığında ilk göze çarpan husus, hazırlık sınıflarındaki öğretim süresinin 1923 yılında iki yıla düşürülüp, derslerin çeşidi artırılırken bunların öğretimine ayrılan sürenin azaltılmasıdır. 1922 yılında üç yıllık hazırlık öğretimi içindeki 9 çeşit dersin haftalık toplam saati 69 iken, 1923 'de 14 çeşit ders için 60 saat ayrılmıştır. Yine 1923'deki programa Mâlûmât-1 Sıhhiye, İlâhî ve Farsça dersleri, program haricinde görülmek üzere Muhâzarât ve Terbiye-i Bedeniye dersleri ilave edilmiş, bazı dersler ise farklı adlarla her iki programda da yer almıştır. 1922 programinda yer verilen Tarih-i İslâm ve Ilmihal dersleri 1923 programında Tarih ve Siyer Musahabeleri ile Müsâhabât-ı Diniye ve Ahlâkîye şeklinde isimleri deģiştirilerek, Arapça ve Coğrafya derslerine ise aynı isimle fakat daha az yer verilmiştir. Din dersleri ile bunun dışında kalan ve kültür dersleri olarak zikredeceğimiz derslerin genel ağırlıklarına bakılınca 1922 programında din derslerinin 26, kültür derslerinin 43 saatlik (\%37-\%63), 1923 programında ise İlâhî dersi de bu kategoriye alındığı hâlde din derslerinin 23 , kültür derslerinin 37 saatlik ağırlığının (\%38-\%62) olduğu görülmektedir.

${ }^{17}$ Bu dersin adı programın tablolar halinde verildiği kısımda Tarih ve Siyer Musahabeleri adı ile geçmesine rağmen içeriği ile bilgilerin verildiği kısımda Siyer ve Menâkıb Musâhabeleri adını taşımakta, içeriğj ise $\mathrm{Hz}$. Peygamber'in hayatı (siyer) ile ilgili konulardan oluşmaktadır. Bk. Dârü'l-Hilâfe Medreseleri Ders Cetvelleri ve Müfredat Programı, s. 8, 17-19. 
Böyle bir düzenlemenin öğrencilerin hem genel eğitimi hem de din eğitimi açısından doğru olduğu kanaatindeyiz. Nitekim Dârü'l-Hilâfe Medreseleri için hazırlanan talimatta, ilk öğretim ikinci kademeye ${ }^{18}$ denk olan İptidâ-yı Hâriç ya da Tâli Kısm-1 Evvel kısmına yaşı 13'ten aşağı olmayan iptidai veya hazırlık sınıfi mezunu öğrencilerin kabul edileceği belirtilmektedir ${ }^{19}$. Bu durumda hazırlık sınıflarının amacı, medresenin asıl sınıflarına kabul edilecek iptidai tahsili almamış öğrencileri bu seviyede yetiştirmektir. Program, bu yıllardaki iptidai programı ile karşılaştırıldığında, hem öğretim süresi hem de yer verilen dersler ve ağırlıkları itibarıyla birbirine benzedikleri; ancak medrese hazırlık sınıflarında, din öğretimine ve Arapça'ya bu kurumun amacına uygun olarak daha çok yer verildiği görülecektir ${ }^{20}$. Diğer taraftan aşağıda belirteceğimiz üzere hazırlık sınıfından sonraki ilk aşama olan İptidâ-yı Hâriç veya Tâli Kısm-1 Evvel'deki ders ağırlıklarının da hazırlık sınıflarındakine benzemesi, birbirinin devamı olan bu iki program arasındaki tutarlılığı gösterir.

1923 yılında hazırlanan proğramda yer alan din öğretimi ile ilgili derslerin içeriği incelendiğinde her iki sınıfta altışar saat yer verilen Kur'ân1 Kerim dersinde her gün yarımşar saat Kur'ân okutulacak, ayrica ilk sınıfta Âdiyat, ikinci sınıfta Duha suresine kadar ezberletilecek, ikinci yılın sonunda öğrenciler Fecr suresine kadarki kısmı ezberleyeceklerdir. Hatta talebelerin istekli ve yetenekli olduğu görülürse idare ve muallimin takdiriyle ezberlenecek kısım daha da artırılabilecektir. Tecvid öğretimi de bu ders içerisinde gerek yüzüne gerekse ezber okumaları sırasında uygulamalı olarak yapılacaktır ${ }^{21}$.

${ }^{18}$ Maarif-i Umumiye Nizamnamesi ile birlikte ilk öğrenimin ikinci basamağı olarak kabul edilen Rüş̧iye mektepleri 1913 yılında hazırlanan Tedrisât-l Iptidâiye Kanun-ı Muvakkan ile kaldırılarak ilk öğretimin süresi alı yıla çıkartılmıştır. Bk. H. Ali Koçer, Türkiye'de Modern Eğitimin Doğuşu, Uzman Yay., Ankara 1997, s. 91, 195. Bu gelişmelere rağmen medreselerdeki akademik yapının mevcut hâli 1913 yılındaki değişimden medresenin etkilenmeyerek 1914 yılındaki csas yapısını muhafaza etmeye devam ettiğini göstermektedir. Bu itibarla biz bu yapının maarif mektepleri ile karşılaştııılırken İptidâ-yı Hâriç (Tâli Kısm-ı Evvel)'in ilk ögrretimnin ikinci kademesi konumundaki rüştiye, İptidâ-yı Dahil (Tâli Kısm-ı Sâni)'in orta öğrctiın kurumları olarak idadiler ile denk kabul edilmesi gerektiği görüşündeyiz.

19 "Dârü'l-Hilâfeti'l-Aliyye Medáris Tâlimatnamesi", s. 35.

${ }^{20}$ Medreselerin amacı göz önüne alındığında, hazırlık sınıflannın din ve genel kültür derslerine verilen ağırlık bakımından iptidailerden daha uygun bir yapıya sahip olduğu görülmektedir. 1915 yılında iptidailer için hazırlanan altı sınıflı programda öğrencilerin tahsilleri boyunca okuyacaklanı haftalık toplam 180 saat içerisinde Kur'an-ı Kerim ve Mâlûmât-ı Diniye dersine 19 saat aynılmaktadır. Bk. Mekâtib-i Iptidaiye Ders Müfredan (Altu, Beş, Dört ve Ü̧ Dershane ve Muallimli Mekteplere Mahsus), Maarif-i Umumiye Nezareti, Matbaa-i Âmire, İstanbul 1329, Tablo 1.

${ }^{21}$ Dârü'l-Hilâfe Medreseleri Ders Cenvelleri ve Müfredat Programı, s. 14. 
Musâhabât-1 Diniye ve Ahlâkiye derslerinde inanç, ibadet ve ahlâkla ilgili konulara yer verilmektedir. İlk sinıfta Allah'a, peygamberlere, kitaplara, meleklere, kadere, âhirete, hayrın ve şerrin Allah'tan geldiğine iman, Kelime-i Tevhid ve Şehâdet'in izahı, Allah'a, Peygamberimize ve Kur'ân'a karşı görevlerimiz konularından sonra ahlâkla ilgili konulara geçilmektedir. Bu çerçevede doğruluk, sözünde durmak, emanete riayet, ebeveyn, ögretmenlere, arkadaşlara, din kardeşlerine ve bütün insanlara karşı görevlerin yanısıra; herkese karşı iyi niyetli ve sevgi ile yaklaşmak, kibirlenmemek, başkalarının mektup ve yazılarına bakmamak, kimseyle alay etmemek, kötü sözler sarfetmemek, merhametli olmak, hiç ölmeyecekmiş gibi dünya hemen ölecekmiş gibi âhiret için çalışmak ve tembellik etmemek gibi konulara yer verilmektedir ${ }^{22}$. İçerikte yer verilen Cenâb-1 Hakk'ı asla hatırdan çıkarmamak, her iyiliğin başının Allah sevgisi ve Allah korkusu olduğu gibi din eğitimi içinde son derece önemli, düstur niteliğinde prensiplere yer verildiği gözden kaçmamaktadır.

Aynı dersin ikinci sınıftaki müfredatında abdest, namaz, oruç, zekat, hac, beden, çevre, yiyecek ve içeceklerin temizliği yanısıra ayrıca kalp temizliği konularına yer verilmektedir. Abdest, namáz, oruça ait bazı hadislerin mealine yer verilmesi talebelerin bilgilerinin temel kaynaklardan beslenmesi açısından yerinde kabul edilmelidir. Yine koğuculuk, iftira ve dedikodu yapmanın oruca tesiri konusuna yer verilmesi yanında, Allah'ın verdiği nimetlere şükretmenin önemine temas edilerek yoksullara yardımın teşvik edilmesi; ayrıca aileye, komşulara, vatana ve devlete karşı görevlerin yerine getirilmesinin dinî birer vecibe olduğuna temas edilmektedir. Bu durum kanaatimizce, dinî bilgilerin kişinin kendisi ve yaşadığı çevredekilere karşı birer davranı̧̧ olarak benimsetilmesi, böylece dinin ögüülerinin yaşantıya aktarılması noktasından yerinde ve doğru olarak nitelendirilmelidir ${ }^{23}$. Konuların geneline bakıldığında ağırlığın Ahlâk ve davranışa verilmesi, din derslerindeki amacın sadece bilgi aktarılması değil, bunun yanısıra davranışların da kazandırılmasının hedeflendiğini ortaya koymaktadır. Konular arasında yer verilen abdest ve namaz öğretiminde uygulama yöntemine başvurulması gerektiği hususunda bilgi verilmemektedir.

Yine hazırlık sınıflarında yer verilen Tarih ve Siyer Musâhabeleri dersi içinde $\mathrm{Hz}$. Peygamber' in yaşadığı dönemdeki olaylar anlatılmakta; ancak olaylar sadece kronolojik olarak sıralanmayarak bunlardan alınması gereken derslere de zaman zaman yer verilmektedir. Mesela, Mekke döneminde karşılaşılan sıkıntılar anlatılırken Hak yolunda gösterilen sebatın önemine

\footnotetext{
${ }^{2}$ Dârü'l-Hilâfe Medreseleri Ders Cetvelleri ve Müfredat Programı, s. 15.

${ }^{23}$ Dârü'l-Hilâfe Medreseleri Ders Cetvelleri ve Müfredat Programi, s. 16.
} 
temas edilmektedir. Yine bu derslerde Hz. Peygamber'in sahip olduğu tarihî §̧ahsiyeti ön plana çıkartılmaktadır ${ }^{24}$.

II. Meşrutiyet yıllarında ilköğretimin altı yıla çıkartılmasından sonra iptidailer için hazırlanan programda medreselerin hazırlık sınıflarına denk kabul edilebilecek ilk dört smıfta yer verilen Kur'ân-1 Kerim ve Mâlûmât-1 Diniye derslerinin müfredatı içinde de aynı konulara yer verildiği , görülmektedir ${ }^{25}$.

1923 yılında hazırlanan program ve ders içeriklerine yer verilen kitabın başındaki açıklamada, Dârü'l-Hilâfe Medreseleri için hazırlanan talimatta, Hazırlık ve Tâlî Kısm-ı Evvel (İptidâ-yı Hâriç) için bir tam saat olarak belirlenen ders süresinin rûhiyat ve terbiye (psikoloji ve eğitim) alanlarındaki yeni tesbitler dikkate alınarak 40-50 dakikayı geçmemesi gerektiği pedagojik gerekçeler ileri sürülerek, 50 dakika olarak belirlendiği ifade edilmektedir ${ }^{26}$.

1923 yılında hazırlanan progranda ders haricinde yer verilen Muhâzarât dersinin medrese öğretiminin amacı açısından son derece isabetli olduğu düşüncesindeyiz. Hazırlık sınıfları ile beraber sonraki Tâli Kısm-ı Evvel ve Sâni aşamalarında da yer verilen bu etkinliğin içeriği ve uygulama yöntemi hakkında geniş bilgi verilmiştir ${ }^{27}$. Perşembe günleri öğleden sonra haftada bir saat olarak yapılacak bu etkinliğ,in amacı talebelerin öğrenim ve gelişim seviyeleri de dikkate alınarak belirlenecek konular üzerinde duygu ve düşüncelerini serbestçe ortaya koyabilme ve savunabilme yeteneklerinin geliştirilmesi olarak belirtilmektedir. Her sınffta müstakil olarak veya bütün talebelerin katılımı ile yapılabilecek bu etkinlikte, belirlenen konu üzerinde sınıfta müderris ile talebeler karşlıklı konuşup tartışma yapacaklar ve konu müderris tarafından toparlanarak sonuçlandırılacaktır. Konunun sınıf içinde tartışılması esnasında müderrisin rahat bir ortam oluşturarak herkese söz hakkı vermesi, konuşmaktan sıkılanları teşvik edip cesaretlendirerek bütün talebelerin katılımını sağlaması, yanlış düşünceleri düzeltmesi, doğru ve yerinde düşünceler ileri sürenleri ödüllendirmesi gerekmektedir ${ }^{28}$. Bunun dışında etkinlik yine belirlenen bir konuda bir talebenin medresedeki bütün talebe ve müderrislerin huzurunda konferans vermesi şeklinde de yapılabilecektir. Kitapta ayrıca, anı-baba sevgisi hakkında örnek bir ders işlenişine de yer verilmiştir.

24 Dârü'l-Hilâfe Medreseleri Ders Cetvelleri ve Müfredat Programi, s. 17-19. Programda yer verilen İlâhî dersinin içeriğinin bulunduğu sayfa basım hatası sonucu kitapta yer almamaktadır.

${ }^{25}$ Mekâtib-i Iptidaiye Ders Müfredau (Bir ve Iki Dershane ve Muallimli Mekteplere Mahsus), Maarif-i Umumiye Nczareti, Matbaa-i Âmire, İstanbul 1329, s. 1-4.

${ }^{26}$ Dârü'l-Hilâfe Medreseleri Ders Cetvelleri ve Müfredat Programu, s. 2; "Dârü'l-Hilâfeti'lAliyye Medâris Tâlimatnamesi", s. 22, mad. 27

${ }^{27}$ Dârü'l-Hilafe Medreseleri Ders Cetvelleri ve Müfredat Programt, s.103-118.

${ }^{28}$ Dârü'l-Hilâfe Medreseleri Ders Cetvelleri ve Müfredat Program, s.106-107. 
Etkinliğin özellikle sınıf içinde uygulaması için getirilen esaslar bugünkü eğitim çalışmaları içinde yer verilen tartışma yönteminin esasları arasında da yer almaktadır ${ }^{29}$. Öğretmen ve öğrencinin, öğretim faaliyetini işbirliği içinde birlikte yürütmesi prensibine dayalı aktif öğretimin benimsendiği söz konusu derste, buluş yoluyla öğretim stratejisine dayalı büyük grup tartışması tekniğinin uygulanmasının ilke olarak belirlendiği görülmektedir. Medreselerin öğretim amacı ile böyle bir yöntemle uygulanacak bir dersin, söz konusu dönemin eğitim şartları içinde programa alınmasını son derece yerinde ve doğru olarak kabul etmek gerekir. Diğer taraftan bu durum, gerçekleştirilen program geliştirme çalışmalarının rastgele değil; kurumun amaçları, yanısıra toplumun ve kişinin ihtiyaçlarının ${ }^{30}$ da göz önüne alınarak yapıldığı hususunda önemli bir ipucu niteliğindedir.

\section{Tâlî Kısm-ı Evvel (İptidâ-yı Hâriç)}

TABLO 3 : 1922 Yılında DHA Medresesi İptidâ-yı Hâriç Kısmı İçin Hazırlanan Program

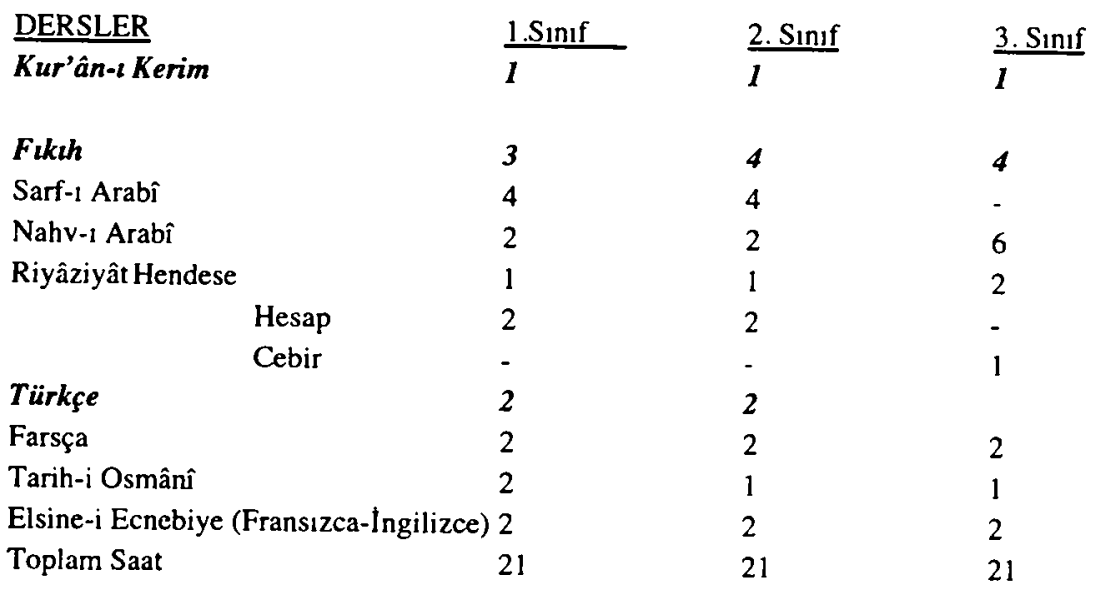

29 Özcan Demirel, Genel Öğretim Yöntemleri, Usem Yay., Ankara 1994, s. 47-48: Leyla Küçükahmet, Ögretimde Planlama ve Değerlendirme, s. 90.

${ }^{30}$ Eğitimde program geliştirme çalışmaları sırasında göz önünde tutulması ilkeler konusunda bilgi için. Bk. Vanş. Eğitimde Program Geliştirme, s. 270-277. 
TABLO 4 : 1923 Yılında Dârü'l-Hilâfe Medreseleri Tâlî Kısm-ı Evvel (İptidâ-yı Hâriç) İçin Hazırlanan Ders Programı

\begin{tabular}{|c|c|c|c|}
\hline DERSLER & 1. Sinif & $\underline{2 . S i n i f}$ & $\underline{\text { 3. Sinif }}$ \\
\hline 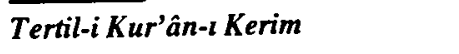 & 2 & 2 & $\cdot$ \\
\hline Ulûm-ı Diniye & 2 & 3 & 3 \\
\hline Arabî(Sarf ve Nahiv) & 6 & 5 & 6 \\
\hline \multicolumn{4}{|l|}{ Mükâleme, Kıraat ve Tatbikat-ı } \\
\hline Arabiye & 4 & 4 & 4 \\
\hline $\begin{array}{l}\text { Türkçe ve Hüsn-i Hat (Imla, Kavâid, } \\
\text { Kıraat, Kitabet) }\end{array}$ & $5^{* *}$ & 5 & 3 \\
\hline Farisî & 2 & 1 & 1 \\
\hline Lisan-1 Ecnebî (Fransızca) & 2 & 2 & 2 \\
\hline Hesap & 2 & 2 & - \\
\hline Cebir & - & - & 2 \\
\hline Hendese & 1 & 1 & 2 \\
\hline Tarih & 2 & 2 & 2 \\
\hline Cografya & 2 & 1 & 1 \\
\hline Mâlûmât-ı Medeniye ve Hukukiye & - & 2 & 3 \\
\hline Mâlûmât-1 Sılhhiye & - & - & 1 \\
\hline Muhâzarât & (Ders haricinde) & & \\
\hline Terbiye-i Bedeniye & (Ders haricinde) & & \\
\hline Yekûn & 30 & 30 & 30 \\
\hline
\end{tabular}

Tâlî Kısm-ı Evvel (Iptidâ-yı Hâriç) programlarına bakıldığında öğretim süresinin her ikisinde de üç yıl olduğu; ancak 1922 yılında her yıl toplam 21 olan ders saatinin, 1923 yılında 30'a yükseltildiği ve Coğrafya, Mâlûmât-1 Medeniye ve Hukukiye, Mâlûmât-1 Sihhiye, Arapça Konuşma, Okuma, Uygulama derslerinin yanısıra, program dışında Muhâzarât ve Beden Eğitimi derslerine yer verildiği görülmektedir. Daha önce 11 çeşit derse yer verilirken 1923 yılında 16 ya yükseltilmiş, buna paralel olarak 1922 yılında bütün öğretim süresi içindeki haftalık saat 63 iken 1923 yılında 90'a yükseltilmiştir. Toplam ders saatinin yükselmesinde, ilave derslerin yanısıra, mevcut derslerin saatleri üzerinde yapılan değişiklikler de etkili olmuştur. Mesela Kur'ân-1 Kerim dersi 1922 programında toplam üç saat iken 1923 yılında sadece ilk iki sınıfta olmak üzere dört saat olarak belirlenmiştir. Fıkıh dersi de 1923 'te Ulûm-ı Diniye adıyla toplam 11 saatten 8 saate indirilmiştir. Arapça dersine 1922 yılında toplam 18 saat yer verilirken 1923 yılında ögrretim süresi hem 29 saate çıkartılarak karşılıklı konuşma, okuma ve uygulama etkinliklerine de yer verilmiştir. Aynı programda daha önce toplam 6 saat olan Türkçe dersi de 13 saate yükseltilmiştir. 1922 yılında bütün öğretim süresi içinde din derslerinin 14, kültür derslerinin 49 (\%23-

• Bu sürenin bir saatinde Hüsn-i Hat dersi yapılacaktır. 
\%77), 1923 yılında ise din derslerinin 12, kültür derslerinin ise 78 (\%13\%87) saatlik ağırlıklarının olduğu görülmektedir ki bu durum din dersleri aleyhine önemli bir gerileme olarak kabul edilmelidir.

1923 programında öncekine göre Arapça ve Türkçe öğretimine ciddî bir ağırlık verilmesi özellikle dikkati çekmektedir. Bunun nedeni; talebelere hem sonraki yıllarda okuyacakları din bilimlerini kaynaklarından öğrenebilme, hem de kendi ana dillerini etkili biçimde kavrama ve kullanabilme yeteneğinin kazandırılması amacı olmalıdır. Nitekim 1923 yılında hazırlanan program ve müfredatta yer verilen çalışmada, Arapça öğretiminde yeni öğretim tarzının gerekliliğine temas edilerek, bu amaçla Tâlî Kısm-1 Evvel (İptidâ-yı Hâriç)'teki Arapça derslerinin müfredatı yenilenerek bu müfredata uygun ders kitabının hazırlanmasına girişildiği, hatta hazırlanan bazı kitapların incelenmeye başlandığı ifade edilmektedir. Bununla birlikte Tâlî Kısm-1 Evvel (İptidâ-yı Hâriç) ve Tâlî Kısm-1 Sânî (İptidâ-yı Dâhil) kısımları için istenilen ölçülerde kitap yazılıncaya kadar eski kitapların okutulmasına devam edilecektir. Arapça öğretiminde sadece dilbilgisi (kavâid) öğretiminin yetersiz kalacağı belirtilerek hem öğrenilen kuralların kahıcı olması hem de talebelerin bu dili konuşup yazabilmeleri amacıyla programa ayrıca Kıraat (Okuma) ve Tatbikât-ı Arabiye (Arapça Uygulama) dersleri ilave edilmiş, bu dersler için ayrı bir kitap hazırlanması çalışmaları da başlatılmıştır ${ }^{31}$. Kanaatimizce bu durum medreselerdeki Arapça ögretiminin verimliliği hususunda son derece doğru ve yararlı bir yaklaşım tarzidir.

Bu yıllarda medreselerde Türkçe öğretimine daha fazla yer verilmesi gerektiği ileri sürülerek, Türkçe'yi yeterince ve hakkıyla öğrenemeyen bir talebenin Arapça'da ne kadar ileri giderse gitsin milletine, mesleğine hatta kendisine yeterince faydalı olamadı̆̆ı; bu asırda dini; milleti ve mesleği müdafaa için "kendisi Türk olan bir din ulemasının" sâhib-i kalem ve diline sahip olması kesinlikle gerekli görülmektedir ${ }^{32}$.

Bu ögretim aşamasındaki programın daha çok genel öğretime yöneldiği görülmektedir. Nitekim II. Meşrutiyet yıllarında öğretim süresi altı yıl olarak düzenlenen iptidailerin son iki yılı ile karşılaştırıldığında medresede din dersleri ve Arapça açısından yoğunluk bulunmakla birlikte diğer derslerin ağırlıklarının birbirlerine yakın oldukları görülmektedir ${ }^{33}$.

1923 programında İptidâ-yı Hâriç'in ilk iki sınıfında Kur'ân öğretimine yer verilmekle beraber içerik hakkında bilgi verilmemektedir. Ulûm-ı Diniye derslerinde ise ilk sınıfta, hazırlık sınıflarında da yer verilen iman ve inanç konularına tekrar yer verilmektedir. Bu çerçevede :

${ }^{31}$ Dârü'l-Hilâfe Medreseleri Ders Cetvelleri ve Müfredat Programı, s. 5.

${ }^{32}$ Dârü'l-Hilafe Medreseleri Ders Cetvelleri ve Müfredat Programi, s. 6.

${ }^{33}$ Mekâtib-i Iptidaîye Ders Müfredatı (Altı, Beş, Dört ve ÜG Dershane ve Muallimli Mekteplere Mahsus), Maarif-i Umumiye Nezareti, Matbaa-i Âmire. İstanbul 1329, Tablo 1. 
1. Allah'ın varlığı ve bunun aklî delillerle ortaya konulması, ardından da Allah'ın sıfatları konusu ile birlikte diğer inanç esaslarına yer verilmektedir. Konunun aktarılması esnasında Allah' in mahiyetinin akıl ile kavranmasının tam olarak mümkün olamayacağı, Allah'ın tasavvur ve tahayyülâtımızın hiçbirine benzemıediği, O'nun zat ve hakikatının his ve akılla kavranamayacağı; zira insan tasavvurlarının gördüğü maddî şeylerden öteye geçemeyeceği, bununla birlikte akılla hakikati idrak edilemeyecek varlıkların inkarının da doğru olmayacağının ruh ve elektrik gibi örneklerle izah edilmesi istenmektedir. Allah'a iman konusuna Onun sıfatları ile devam edilerek, Allah'ın bazı sıfatlarının, insanların da sahip olduğu özelliklerden farklı olduğu vurgulanacaktır.

2. Peygamberlere iman konusu insanların peygamberlere olan ihtiyacı, peygamberliğin ilâhî yönü vurgulanarak açıklanacaktır.

3. Kitaplara iman konusunda diğer kutsal kitaplar kısaca tanitıldıktan sonra Kur'ân'a yer verilecektir.

4. Meleklere iman konusu işlenirken Allah'a iman konusunda da yer verilen görülemeyen varlıkların inkar edilemeyeceği esasına burada da yer verilecektir.

5. Ölümden sonra dirilme ve: âhiret konuları talebenin anlayabileceği şekilde örneklerle anlatılacaktır.

6. Kaza-kader, hayır ve şerrin, her şeyin Allah'tan olduğu inancı açıllanacaktır.

7. Tevekkül ve kanaatin miskinlik ve tembellik demek olmadığı izah edilecektir ${ }^{34}$.

Iptidâ-yı Hâriç'in ikinci sınıfında yer verilen Ulûm-1 Diniye dersinde ise Kelime-i Şehâdet'in ifade ettiği anlam, Kur'ân'da insanlara yüklenen görevlerin kısımları (Ef'âl-i Mükellefîn), ibadetin anlamı ve gerekliliği, ibadetin vicdanî ve aklî bir vazife olduğu, insanların güzel ahlâk sahibi olmasına ve kardeşlik duygusunun gelişmesine katkısının olacağı belirtilecektir. Bu hususta özellikle ibadetin geniş anlamda Allah rızasını kazanmak amacıyla insanın kendisi ve kendisi dı̧̧ındaki bütün insanların yararına yapılan her işin, vatan ve din uğrunda yapılan her fedakarlığın İslâm inancına göre ibadet olduğunun hadislerle ortaya konulacağı esasının getirilmesinin, ibadetin gerçek anlamıla bilinmesi ve benimsenmesi amacına ulaşma hususunda isabetli olduğunu belirtmeliyiz. İbadetlerden bahsedilirken, yapılması istenilen her ibadetin insan ve toplum yararı bakımından bir hikmetinin olduğunun vurgulanması gerektiği, bununla birlikte ibadetlerin yapılmasındaki esas amacin bu hikmetin de ötesinde sırf bir vazife olduğu için yapıldığının ayrıca belirtilmesi gerektiğinin ifadesi ${ }^{35}$, ibadetin gayesi noktasında bugün. de mutlaka dikkate alınması gereken çok mühim bir husustur. Yine namazdan bahsederken, Allah'ı unutmanın her

\footnotetext{
${ }^{34}$ Dârü'l-Hilafe Medreseleri Ders Cetvelleri ve Müfredat Programi, s. 31-32.

${ }^{35}$ Dârü'l-Hilafe Medreseleri Ders Cetvelleri ve Müfredat Programu, s. 33.
} 
türlü fenalığın kaynağı olduğu, bunun önlenmesi noktasında namazın önemli bir vasıta olduğunun belirtilmesini din dersinin amacı açısından çok önemli gördüğümüzü belirtmeliyiz. Bu çerçevede öğrencilerin gelişim seviyesi dikkate alınarak sadece ibadetlerle ilgili bilgilerin aktarılması ile yetinilmeyip aynı zamanda akıl ve duyguların da harekete geçirilerek davranışa dönüştürülmesi amaçlanmaktadır ${ }^{36}$. İbadetlerin amacı hakkındaki bilgilerin yanısıra ayrıca temizlik ve abdest, cuma, bayram, teravih ve cenaze namazları hakkında bilgiler verilecektir.

Yine bu ders için hazırlanan müfredata göre; namaz bahsinin sonunda bazı âyetler yazılarak tercüme ve izah edildikten sonra ezberletilecektir. Bu âyetlerin ahlâkî davranışlar, içki ve kumarın zararları, milletlerin felaketlerine sebep olan davranışlar, çalışmanın gerekliliği, dostluk ve kardeşlik duygularının nasıl güçlendirileceği, dost ve düşmanların nasıl belirleneceği gibi insanın toplum içindeki görev ve sorumluluklarını belirten, toplumun huzurunu bozan kötü alışkanlık ve davranışları önleyecek iyi ve doğru olan davranışlara yöneltecek âyetler olmasına özel bir önem verilecektir ${ }^{37}$.

Bu öğretim basamağının son sınıfında üç saatlik dersin bir saatinde yine oruç, zekat ve hac ibadetleri ile ilgili bilgiler verilerek bu ibadetlerin amacı ve anlamı üzerinde durularak temas edilecektir. Mesela, orucun insanın iradesinin güçlenmesine olan katkısı, insan sağlığına yararları yanında içtimaî yararları üzerinde durulacak, benzer şekilde zekatın, sosyal yardım ve dayanışma açısından ülkeye ve kişinin kendisine sağlayacağı yararlar belirtilerek çalışmanın bütün Müslümanlar üzerine görev olduğu, toplumda muhtaç olanlara yardım etmenin de bir görev olduğu zekat kurumu ile bağ kurularak işlenecektir. Dersin diğer iki saatinde ise Münâkehât ve Müfârekât (Evlenme ve Boşanma) konularına yer verilerek dinimizin evlilik ve boşanma konusundaki esaslarının yanısıra aile ve nikahın fert ve sosyal açıdan önemi, tek eşliliğin esas oluşu ve boşanmanın hoş görülmeyen bir durum olduğu gibi konulara da temas edilerek bu bilgilerin günlük hayatla bağlantısı kurulacaktır ${ }^{38}$.

Yukarıda içeriği hakkında bilgi verdiğimiz Ulûm-1 Diniye dersinde, ilk sınıfta iman, ikinci sınıfın tamamı ile son sınıftaki bir derste ibadet konularına yer verilmektedir. Burada, bir önceki öğretim basamağı olan hazırlık sınıflarında da yer alan aynı konuların bulunması tekrar olmasına rağmen, gereksiz ve anlamsız olmadığı ileri sürülebilir. Çünkü İptidâ-yı

\footnotetext{
36 Böyle bir yaklaşım Bloom ve diğerleri tarafından geliştirilen, kognitif (bilişsel), efektif (duyuşsal) ve psikomotor (davranışsal) alanlardan oluşan eğitim amaçlannın taksonomisine de uygun görünmektedir. Bu konu için, Bk. Benjamin S. Bloom, Insan Nitelikleri ve Okulda Öğrenme, Çev: D. Ali Özçelik, MEB Basımevi, Ankara 1979; Leyla Küçükahmet, Ögretimde Planlama ve Değerlendirme, s. 14-17.

${ }^{37}$ Dârü'l-Hilâfe Medreseleri Ders Cetvelleri ve Müfredat Programı, s. 34.

38 Dârü'l-Hilâfe Medreseleri Ders Cetvelleri ve Müfredat Programı, s. 36-37.
} 
Hâriç sınıflarına yaşları 13-18 arası talebelerin kabul edileceği göz önüne alındığında, bu yaşlar arasındaki çocukların gelişim seviyeleri itibarıyla akıllarını kullanma ve sorgulama yeteneklerinin gelişmeye başladığı ve soyut kavramları anlayabilecek seviyeye geldikleri göz önüne alınarak, iman konularının akla hitap eder biçimde: tekrar ele alınmasını doğru kabul etmek gerekir.

Diğer taraftan müfredat içerisinde ahlâk ile ilgili konulara müstakil olarak yer verilmediği, bu konuların daha çok yeri geldikçe iman ve ibadet konularıyla bağlantılı olarak işlendiği gözden kaçmamaktadır ${ }^{39}$. Şüphesiz, doğruluk ve gerekliliğinin hissedilerek benimsenmesi ve fiilen yaşanması esas olan ahlâkî konuların, dinin temel prensipleri olan iman ve ibadet konuları ile birlikte verilmesi, yine dinin diğer bir temel prensibi olan ahlâk ile bütünlüğünün sağlaması açısından yanlış olmayacağı da açıktır. Ancak biz yine de ahlâk konularının ayrıcia ele alınmasının en azından bu hususların vurgulanması açısından daha doğrı olacağı kanaatindeyiz. Bu sınıfta Ulûm-ı Diniye dersi müfredatında evlenrne-boşanma konularına yer verilmesinin gerekli olduğu düşüncesinde değiliz. Şayet, amaç dinimizin aile kurumuna verdiği önem ve bunun sosyal ve ferdi açıdan değerinin öğretimi ise bu amacın ahlâkla ilgili diğer konulara da yer verilerek gerçekleştirilmeye çalışılması daha doğru olurdu.

Yine Ulûm-1 Diniye derslerinde öğretimin Türkçe yapılması, özellikle ilk yıllarda talebelerin yeterli derecede Arapça bilmemeleri yüzünden karşılaştıkları zorluklar dolayısıyla uygun görülmeyerek, Tâlî Kısm-ı Sânî (Iptidâ-y1 Dâhil)'e kadar bu derslerin Türkçe, daha sonra programda yer alan Fıkıh dersinin Arapça olarak okutulması kararlaştırılmışıı ${ }^{40}$. Din derslerinin özellikle bilimsel araştırma amacı taşımayan ilk ve orta dereceli öğretim kurumlarında Türkçe okutulmasınin daha doğru olduğu düşüncesindeyiz; çünkü bu aşamalarda din derslerinin okutulmasındaki asıl amacın din ile ilgili temel bilgilerin öğrenciye kazandırılması olduğu göz önüne alındığında mutlaka Arapça eserlere başvurulmasının gerekmediği açıktır. Yüksek din öğretiminde ise mevcut eserlerin önemli bir kısmının Arapça olarak yazılmış olması gerçeği göz önüne alındığında bu dilin bilinmesi gerekli olabilir. Bunun dışında, Arapça öğretimi ile din bilimleri öğretiminin, özellikle de din eğitiminin birbirinden ayrı düşünülmesi gereken konulardır.

Müfredatta, ilk sınıftaki konuların Dinî Dersler adlı kitabın ilk kısmından, üçüncü sınıftaki evlenıme-boşanma konuları dışındaki konuların ise ikinci kısmından takip edileceği belirtilmektedir ${ }^{41}$. Yazarı ve basım yeri belirtilmeyen bu esere ulaşmamız mümkün olamamıştır.

${ }^{34}$ Müfredatta ahlâk konularına yer verilmeyerek, sadece bahsedilen konular tamamlandıktan derste takip edilmesi istenilen kitabın ahlâk kısmının özet olarak okutulması istenmektedir. Bk. Dârü'l-Hilâfe Medreseleri Ders Cetvelleri ve Müfredat Programi, s. 35.

41) Dârü'l-Hilâfe Medreseleri Ders Cetvelleri ve Müfredat Programı, s. 5-6.

${ }^{41}$ Dârü'l-Hilâfe Medreseleri Ders Cetvelleri ve Müfredat Programı, s. 32, 35. 


\section{Tâli Kısm-ı Sâni (İptidâ-yı Dâhil)}

TABLO 5 : 1922 Yılında DHA Medresesi İptidâ-yı Dâhil Kısmı İçin Hazırlanan Program

\begin{tabular}{|c|c|c|c|}
\hline DERSLER & 1.Sinif & 2. Sinif & 3. Sinif \\
\hline Akâid & - & - & 3 \\
\hline Fıkıh & 4 & 3 & - \\
\hline Usûl-i Fıkıh & - & 2 & 3 \\
\hline Siyer-i Nebevî & 2 & 1 & 1 \\
\hline Nahv-i Arabî & 6 & 5 & - \\
\hline Belagat-i Arabî & - & \multicolumn{2}{|c|}{ 2(Meânî) 5(Meânî) } \\
\hline Vaz' ve Aruz & - & 2 & - \\
\hline Mantık & - & 2 & 1 \\
\hline Âdâb ve Münâzara & - & - & 1 \\
\hline Ferâiz ve İntikal Kanunu & - & - & 2 \\
\hline İlm-i İçtima’ & 2 & - & - \\
\hline Edebiyât-ı Türkî & 2 & - & - \\
\hline Riyâziye Cebir & 2 & - & - \\
\hline Müsellesât & - & 2 & - \\
\hline Heyet & - & - & 3 \\
\hline Elsine-i Ecnebiye(Fransızca-Ingilizce) & 2 & 2 & 2 \\
\hline Toplam Saat & 20 & 21 & 21 \\
\hline
\end{tabular}

TABLO 6 : 1923 Yılında Dârü'l-Hilâfe Medreseleri Tâlî Kısm-ı Sânî (İptidâ-yı Dâhil) İçin Hazırlanan Ders Programı

$\begin{array}{llll}\text { DERSLER } & \underline{1 . \text { Sınıf }} & \underline{2 . \text { Sınıf }} & \frac{3 . \text { Sınıf }}{2} \\ \text { Tefsir-i Şerif } & - & - & 1 \\ \text { Hadis-i Şerif } & 1 & 1 & 2 \\ \text { Fıkıh } & 3 & 3 & 2 \\ \text { Ilm-i Tevhid } & - & 1 & 2 \\ \text { Ferâiz ve Usûl-i Intikal } & - & - & - \\ \text { Arabî (Nahiv) } & 5 & 4 & - \\ \text { Kıraat ve Tatbikât-ı Arabiye } & 2 & 1 & 4 \\ \text { Belâgat-i Arabiye } & - & - & - \\ \text { Vaz' } & - & 1 & 2 \\ \text { Mantık ve Münâzara } & 1 & 2 & - \\ \text { Edebiyat-ı Türkiye } & 2 & 2 & 2 \\ \text { Lisan-ı Ecnebi (Fransızca) } & 2 & 2 & - \\ \text { Fizik } & 2 & 1 & 1 \\ \text { Kimya } & 1 & 1 & 2 \\ \text { Ulûm-ı Tabiiye } & 1 & & \end{array}$




$\begin{array}{llll}\text { Riyaziyat Cebir } & 2 & - & - \\ \text { Müsellesât } & - & 2 & - \\ \text { Hey'et } & - & - & 3 \\ \text { Tarih } & 2 & 1 & - \\ \begin{array}{l}\text { Mâlûmât-1 Hukukiye } \\ \text { Muhâzarât }\end{array} & - & 1 & 1 \\ \text { Terbiye-i Bedeniye } & \text { (Deis haricinde) } & & \\ \quad & \text { (Deis haricinde) } \\ \quad \text { Toplam Saat } & 24 & 24 & 25\end{array}$

Bu öğretim aşamasındaki programlar karşılaştırıldığında ilk göze çarpan husus, 1922 yılındaki programda 16 çeşit derse yer verilirken bu sayının 1923 'te 21 'e çıkartılmış olmasıdır. Buna paralel olarak haftada 62 saat olan toplam ders süresi de 1923 yılında 73'e çıkartılmıştır. 1923 yılındaki programda Tefsir, Hadis, Fikıh ve İlm-i Tevhid gibi din derslerinin çeşit olarak arttığı ve özel alanlara doğıu yönlendirildiği de dikkati çekmektedir. Ayrıca eskisinden farklı olarak Tarih, Fizik, Kimya, Ulûm-1 Tabiiye ile program haricinde Malûmât-1 Hukukiye ve Muhâzarât dersinin konulduğu, Usûl-i Fıkıh, İlm-i İçtima' (Sosyoloji) ve Siyer derslerinin kaldırıldığı, Türk Edebiyatı ders saatinin artırıldığı, Arapça dersinde uygulamaya yer verildiği görülmektedir. 1922 yılında ögretim süresi içinde din derslerinin 19, kültür derslerinin 43 saatlik ağırlığının ( \%31-\%69), 1923 yılında ise din derslerinin 16 , kültür derslerinin 57 (\%22-\%78) olduğu görülmektedir. Orta dereceli öğratim kurumları olarak düzenlenen medreselerin, söz konusu son iki öğretim basamağında alan öğretimi yerine genel kültür öğretimine daha fazla yer verildiğini açıkça ortaya koyan bu durum, orta dereceli medreselerin, genel öğretim kurumları ile denkliğinin sağlanması çabası olarak izah edilebilir. Bununla birlikte medreselerin orta kısım programlarında, yüksek kısıma hazırlık ve temel teşkil etmesi düşüncesi ile Arapça ve din öğretimi alanı ile ilgili meslek derslerine diğer orta dereceli kurumlara göre çok daha yoğun olarak yer verilmektedir.

Orta dereceli öğretim kurumları olarak kabul edilmesi gereken Tâli Kısm-1 Evvel ve Sâni medreselerindeki öğretim programlarında meslek dersleri ile kültür dersleri arasındaki oranın bu kurumlar için önceki yıllarda hazırlanan programlar dikkate alındığında, giderek meslek dersleri aleyhine geliştiği gözlenmektedir. Nitekim 1918 yılında aynı aşamalar için hazırlanan programlara ${ }^{42}$ bakıldığında buradaki meslek derslerinin ağırlığının $\% 38$ ve $\%$ 42 arasında değiştiği görülmektedir.

1923 yılında İptidâ-yı Dâhil kısmı için hazırlanan müfredatta Tefsir dersine son sınıfta iki saatlik bir yer ayrılıp Kur'ân'daki kısa surelerden başlanarak en az bir cüzün tamamlanacağı belirtilmektedir. Her üç sınıfta da birer saat yer ayrılan Hadis derslerinde ahlâkî ve sosyal konulardaki hadislere özellikle yer verileceği ve bu konuda hazırlanan bir ders kitabının

${ }^{42}$ Ceride-i Ilmiye, 4. Sene, Aded 37, (Zilkade 1336), s. 1120-1121. 
basılmak üzere olduğu belirtilmekte, ayrıca Birgivî'nin Usul-i Hadis kitabının da okutulacağı ifade edilmektedir ${ }^{43}$. Müfredatta, Hadis öğretiminde dikkate alınması gereken noktalar 8 başlık altında toplanmıştır :

1. Hükmü yalnız Hz. Peygamber'in yaşadığı döneme ait olan değil, günümüze de uzanan hadisler seçilmelidir.

2. Şia ve Mutezile hakkında olduğu gibi Müslüman topluluklar arasında ayrılık oluşturmak için uydurulan hadislerden kaçınılmalıdır.

3. Hükmü daha sonraki hadislerle kaldırılan (mensuh) hadislerin öğretiminden kaçınılmalıdır.

4. Ahlâk ve âdâba dair hadislerin bu hususta esas ve umde olanları ile yetinilip, mesela, ham yemenin durumu, giyim tarzı, erkeklerin sürme kadınların kına kullanmaları gibi zaman içerisinde geleneğe bağlı olarak değişebilen konuları içeren hadislere yer verilmemelidir.

5. Ahkâm konusunda sadece güvenilir hadislere yer verilmelidir. Adâb, ahlâk ve hikmete dair olanlarına ise müderrisin bunların güvenilirlik durumunu da açıklaması kaydıyla yer verilmesi mümkündür.

6. Müderris öğretimini söz konusu edeceği hadisin içeriği ile günlük olayları mukayese ederek, hadisin o gün için ifade ettiği değeri açıklamalıdır.

7. Hadis öğretimi yapanın amacı Müslümanları, Hz. Peygamber'in sahip olduğu güzel ahlâk doğrultusunda eğitmek ve onların da bu vasıflara sahip olmalarını sağlamak olmalıdır.

8. Hadis muallimi, Hz. Peygamber'in hedeflediği dinî ve medenî esasları açıklayarak, ümmetini ilerlemeye, ilim ve irfana teşvik ettiğini böylece onları iki dünyada da mutlu kılmayı amaçladığını her fırsatta anlatmalıdır ${ }^{44}$.

Hadis öğretimi esnasında söz konusu edilen bu esasların genel olarak din eğitimi ve öğretimini hedefleyen medrese tahsili içinde son derece isabetli hatta günümüz için de geçerli olduğunu belirtmeliyiz. Bu esaslarla Hadis öğretimi, talebenin içinde hizmet sunacağı toplum için daha faydalı ve bilinçli olmasına, amaçların gerçekleşmesine hizmet edecektir.

Programda ilk iki sınıfta üç, son sınıfta ise iki saat olarak yer verilen Fıkıh derslerinde Kudûrî'nin ${ }^{45}$, Usûl-i Fıkıh'tan ise Sirâciye $e^{46}$ metninin takip edileceği belirtilmektedir ${ }^{47}$.

${ }^{43}$ Dârü'l-Hilâfe Medreseleri Ders Cetvelleri ve Müfredat Programı, s. 59. İmam Birgivî̀nin Risale fi Usuli'l-Hadis adlı bu eseri hakkında bilgi için, Bk. Ahmet Turan Arslan, Imam Birgivî Hayatı Eserleri ve Arap̧̧a Tedrisatındaki Yeri, Seha Neşriyat, İstanbul 1992, s. 105-106; Sadık Cihan, "Muhammed b. Pir Ali Birgivî ve Risale fi Usûli'l Hadis'in Tcrcümesi”, OMÜ Ilahiyat Fakültesi Dergisi, Sayı : 2, Samsun 1987, s. 55-76.

${ }^{44}$ Dârü'l-Hilâfe Medreseleri Ders Cetvelleri ve Müfredat Programi, s. 60-61.

${ }^{45} \mathrm{Bu}$ eser, Hanefí Fıkıhının önde gelen âlimlerinden Ahmet b. Cafer el-Kudûrî (v.362/972)'nin el-Muhtasar adiı eseri olmalıdır. Eser Istanbul'da Tanzimat'ın sonlanndan 
İslam inanç esaslarının öğretiminin konu edildiği İlm-i Tevhid dersine ikinci sınıftan itibaren yer verilmektedir. Bu sınıfta Emâlit ${ }^{48}$ metni okutularak ezberletilecek, üçüncü sınıfta ise bu ilmin amacı, konusu, din ve akıl ilişkisi, Allah'ın varlığı hakkındaki deliller, maddiyûn (materyalist) ve tekâmüliyyûn (evrimci) nazariyelerinin felsefe yoluyla reddi, Allah'ın sıfatları, peygamberlik, vahiy, Kur'ân, ve âhiret gibi konular ayrıntılı olarak tedris edilecektir. Mesela vahiy konusu içinde vahyin mümkün olup olamayacağı, ilham ile arasındaki fark, akıl ve naklin nerelere delil olabilecekleri konuları üzerinde durulacaktır. Benzer şekilde İslâm'ın peygamber inancı ayrıntılı olarak ele alınarak peygamberlerin görevlerinin neler olduğu, ayrıca dinin sosyal bir vakıa olduğu, din ve felsefenin fonksiyonları gibi konulara da yer verilecektir.

Bu konularla ilgili Arapça bir kitabın hazırlanmakta olduğu, hazırlanıncaya kadar Muhammed Abduh'un Tevhid Risalesi ${ }^{49}$, bu eser bulunmadığı takdirde $F \imath k h-\imath$ Ekber Şerhi'nin takip edileceği belirtilmektedir. Müfredatta bu ilmin okutulması ile ilgili olarak izah verilerek, İlm-i Tevhid ya da Kelam'ın aslında din esaslarının müdafaasını konu aldığı, bunun da her devrin düşünce akımlarına göre yeniden ele alınarak düzenlenmesi gerektiği ifade edilmektedir. Bu durumda asırlar önceki konuların bugün aynen okutulmasının yeterli olamayacağı çünkü aradaki zaman içerisinde dine karşı ileri sürülen fikirlerin değiştiği buna karşılık savunma için ileri sürülen fikirlerin de buna göre değişmesi ve geliştirilmesi gerektiği fikri belirtilerek dersin müfredatının bu amaçla yeniden ele alındığı ifade edilmektedir ${ }^{50}$.

İlm-i Tevhid dersinin İslâm Dini'nin temeli olan inançla ilgili konuları kapsadığı bilinmektedir. Kanaatimizce bu konuların ayrı bir derste ele alınması kadar hazırlanan müfredat da doğru unsurlar içermektedir. Çünkü

itibaren birçok kez basılmıştır. Bk. Ahmet Özel, Hanefi Fıkıh Alimleri, TDV. Yay., Ankara 1990, s. 36-37.

46 İslâm miras hukukunda, mirasçılárın terckeden hangi hallerde ne kadar pay alabileceklerinden bahseden Ferâiz ile ilgili bu eser Siraceddin Muhammed b. Mahmud b. Abdürreşid Secâvendî'ye aittir. Bk. Kâtip Çclebi, Keşü'z-Zünûn II, s. 1247.

${ }^{47}$ Dârü'l-Hilâfe Medreseleri Ders Cetvelleri ve Müfredat Programi,s. 61.

48 Siracüddin Ali b. Osman el-Uşî’ye ait ınanzuın olarak kaleme alınan bu eser $e$-Kasidetü'l Lâmiye fi't-Tevhid, Kasidetü'l Yegûlï'l Abd ve Bed'ü-l Emâlî adlanı ile de tanınır. Bk. Kâtip Çelebi, Keş̧ü'z-Zünûn II, s. 1350; Durmuş Özbek, "el-Uşî ve Kasidetii'l Emâlî", SÜIF Dergisi, Say1: 5, Konya 1994, s. 261-308.

${ }^{49}$ Mısırlı ünlü Islâm bilgini Muhammed Abduh ( 1258/1323-1842/1905)'un Kelam ilmine dair bu eseri 1315, 1316 ve 1324 yıllarında Mısır'da basılmıştır. Bk. Yusuf Elyan Serkis, Mu'cemu'l Matbuatü'l Arabiye, Misır 1346-1928, s. 1678-1679. Eser, daha sonra Türkçc'ye de çevrilmiştir. Bk. Muhamrned Abduh, Tevhid Risalesi, Çev : Sabri Hizmetli, Fecr Yay., Ankara 1986.

so Dârü'l-Hilâfe Medreseleri Ders Cetvelleri ve Müfredat Programı, s. 64-66. 
materyalist felsefenin etkili olduğu o yıllarda inançla ilgili birçok konu sorgulanmakta ve bunlara tatmin edici cevaplar aranmaktadır. Müfredat bu sorgulamayı yapar nitelikte görünmektedir. Bu açıklamalara ve müfredatta yer verilen konulara bakıldığında Muhammed Abduh'un eserinin okutulmasının daha doğru ve yerinde olacağı açıkça görülmektedir. Bununla birlikte, düşünce ve muhakemeye dayalı bu tür soyut (mücerred) konuların ana dil dışında Arapça bir eserden okutulmasının, kavramada doğurabileceği zorluklar yüzünden çok isabetli olmadığı düşüncesindeyiz.

\section{Kısm-ı Âlî (Sahn)}

TABLO 7 : 1922 Yıılında DHA Medresesi Sahn (Ấr) Kısmı İçin Hazırlanan Program

\begin{tabular}{|c|c|c|c|}
\hline DERSLER & 1.Sinif & 2.Sinif & 3.S.nin \\
\hline Tefsir & 2 & 2 & 2 \\
\hline \multicolumn{4}{|c|}{ Ehâdísü'l-Ahkâm(Usul-i Hadisle } \\
\hline birlikte) & - & - & 3 \\
\hline Kelâm & 3 & 3 & 3 \\
\hline Fikth & - & - & 3 \\
\hline Usûl-i Fukah & 3 & 3 & - \\
\hline Belâgat-i Arabiye & 4(Beyan) & 2(Bedi') & 6 \\
\hline Edebiyât-I Arabiye & - & 1 & 2 \\
\hline Mantık & 3 & 4 & - \\
\hline Hifzı's-Sihha & - & - & 2 \\
\hline Hikmet-i Tabiiye & 2 & 1 & - \\
\hline Tabiiyât Kimya & 1 & 2 & - \\
\hline Mevâlid & - & - & 2 \\
\hline Hikmet-i Aûka ve Cedîde & - & - & 2 \\
\hline Toplam Saat & 18 & 18 & 18 \\
\hline
\end{tabular}

TABLO 8 : 1923 Yılında Dârü']-Hilâfe Medreseleri Kısm-ı Âlî (Sahn) İçin Hazırlanan Program

\begin{tabular}{|c|c|c|c|}
\hline DERSLER & 1. Sinif & 2. Sinif & 3. Sinıf \\
\hline Tefsir-i Şerif & 2 & 2 & 2 \\
\hline Hadis-i Şerif & 2 & 1 & 1 \\
\hline Usûl-i Fıkıh & 3 & 3 & 3 \\
\hline İlm-i Kelam & 3 & 3 & 3 \\
\hline Ilm-i Ahlâk & - & - & 1 \\
\hline Mecelle & 3 & 3 & 3 \\
\hline Hukuk-ı Tasarrufiye-i Arazi ve Evkâf & 1 & 1 & - \\
\hline Belâgat & 3 & 3 & 3 \\
\hline Ilm-i Nefs & 3 & - & - \\
\hline Mantık-ı Sûn ve Tatbikatı & - & 3 & - \\
\hline
\end{tabular}




\section{Mâba'de't-Tabia'}

Edebiyat-ı Türkiye

Mâlûmât-1 Hukûkiye

Lisan-ı Ecnebî

Terbiye ve İlm-i İçtima'

Toplam Saat

$\begin{array}{lll}- & - & 2 \\ 2 & 2 & 1 \\ - & 1 & 1 \\ 2 & 2 & 2 \\ - & - & 2 \\ 24 & 24 & 24\end{array}$

Dârü'l-Hilâfe medreselerinin yüksek öğretime yer verilen Sahn (Kism-1 Âlî) basamağında ise din bilimler alan öğretimine, her iki programda da yoğun bir ağırlığın verildiği görüilmektedir. Diğer taraftan 1923 yılında programa konulan derslerin çeşit bakımından biraz daha çok olduğu fakat asıl farklılığın programdan kaldırılan ve yeni konulan derslerde olduğu görülmektedir. 1922 yılında Arapça ögretimi için 15 saatlik yer ayrılmışken; bu süre, 1923 yılında 9 saate indirilmiştir. Yine 1922'deki programda yer alan Hikmet-i Tabiiye (Fizik), Kimya, Mevâlid derslerinin yanısıra Hıfzı'sSıhha ile Hikmet-i Atîka ve Ceclide (Eski ve Yeni Felsefe) dersleri de kaldırılmıştır. Aslında bu derslerin konulmasındaki amaç; din bilimleri sahasında yetiştirilecek talebelerin alacakları eğitimin fen ve felsefe ilimleri ile desteklenerek hem bu alandaki gelişmeler hakkında bilgi sahibi olmaları, hem de dinin anlaşılması ve anlatılmasında daha geniş ve tutarlı görüş sahibi olunması arzusudur. Aynı amaç 1923 programında daha etkin bir şekilde takip edilmiştir. Programdan kaldırılan derslere karşılık İlm-i Ruh (Psikoloji), Terbiye ve İlm-i İçtima' (Eğitim ve Sosyoloji), Ahlâk, Mâba'de't-Tabia, Edebiyat-1 Türkiye ve Lisan-1 Ecnebi dersleri programa alınmıştır. 1922 programında Fıkılı ve Usul-i Fıkıh adlarıyla İslâm Hukuku ögretimine toplam 9 saatlik yer ayrılmış iken, 1923 yılında hazırlanan programda Mecelle, Hukuk-ı Tasarrufiye-i Arazi ve Evkâf, Usul-i Fıkıh ve Mâlûmât-ı Hukukiye adlarını taşıyan derslerle 22 saatlik yer verilmiştir. Mantık dersi de 1922 programında 4 saatlik bir yer tutarken, bu süre 1923 'te 3'e indirilmiştir.

Dârü'l-Hilâfe Medresesi'nin programlarından söz ettiğimiz aşamalarının, hem din görevliliği mesleğine hazırlık hem de genel öğretimden kopmamak amacını taşıdığından bu yüzden programlarda, meslek derslerine diğer dengi kurumlardan daha çok yer verilmekle birlikte genel kültür derslerinin ağırlığının meslek derslerinden daha çok yer tuttuğundan bahsetmiştik. Bu aşamalar için bahsettiğimiz amaçlar ile program uygulamaları arasında bir paralellik ve tutarlılığın bulunduğu görülmektedir. Aynı hususun, bu medresenin yüksek kısımı için öncekilerde olduğu kadar geçerli olmadığı ileri sürülebilir. Zira günümüzde de geçerli olduğu üzere yüksek öğretim kurumlarında genel kültür değil alan öğretimi esastır. Söz konusu iki program bu açıdan degerlendirildiğinde 1923 yılında hazırlanmış olanın, amaçların gerçekleştirilmesi noktasında daha ileri

\footnotetext{
Fizik ötesi
} 
seviyede olduğu görülecektir. 1922 yılındaki programda, üç yıllık toplam 54 saatlik ders süresinin 32 saatinin (\% 60) genel kültür, 22 saatinin (\% 40) meslek derslerine ayrıldığı görülmektedir. Halbuki 1923 yılında hazırlanan programda, hem toplam ders süresi 72 saat olarak artırılmış, hem de bu sürenin 33 saati genel kültür derslerine (\% 46), 39 saati $(\% 54)$ ise meslek derslerine ayrılmıştır. Diğer taraftan 1923 yılında meslek derslerinin ağırlığı sadece artırılmakla kalınmayarak İlm-i Nefs (Psikoloji), Ahlâk, Edebiyat-1 Türkiye (Türk Edebiyatı), Terbiye ve İlm-i İçtimâ (Eğitim ve Sosyoloji) gibi meslek derslerin anlaşılması ve uygulanmasına yardımcı olacak derslere de yer verilmiştir. Ders içeriklerine yer verilen çalışmada, Terbiye dersinin din görevlileri için ne kadar gerekli olduğu belirtilerek bu derste talebenin, eğitimle ilgili teorik bilgiler yanında bu bilgileri pratikte kullanma yollarını da öğrenerek hem kendisini hem de başkalarını eğitebilme hususunda dolayısıyla mesleğinde daha başarılı hâle getirilebilecektir ${ }^{51}$.

Yine bu programda yer verilen Lisan-1 Ecnebi dersi ile medrese mezunlarına yabancı dil öğrenmeleri imkânı sağlanırken, şer'î mahkemelerde görev alabilecekleri göz önünde tutuldugunda Mecelle, Hukuk-1 Tasarrufiye-i Arazi ve Evkâf ve Mâlumât-1 Hukûkiye derslerini de meslekî gelişimleri ve programın amacı açısından isabetli uygulamalar olarak görmek gerekir.

Dârü'l-Hilâfe Medresesi'nin yüksek kısmında yer verilen meslek derslerinin içeriklerine bakıldı̆̆ında, bu aşamanın üç sınıfında da iki saat olarak yer verilen Tefsir dersinde, her sınıfta üç uzun surenin tefsirinin yapılması öngörülmektedir. Bu aşama, medresenin son basamağı oldugundan burada takip edilecek yöntemin de farklı olması gerektiği belirtilerek uyulması gereken birtakım açıklamalara yer verilmektedir. Buna göre Tefsir dersleri işlenirken, İslâm dininin ilk kaynağı ve dinî esasların temel dayanağı durumunda olan Kur'ân'ın parça parça nazil olduğu, anlamı kolaylıkla anlaşılabilen (muhkem) âyetlerin yanısıra, anlamı kapalı (müteşâbih) olan âyetlerin de var olduğu gözden kaçırılmayacaktır. Kur'ân'ın içeriğinde âyetler arasında tezat yok ise de âyetlerin indiriliş sebepleri (esbâb-1 nüzul) ile ilgili bilgiler arasındaki bazı ihtilaflardan dolayı anlamları farklı ve birbirine zıt gibi görünen bazı âyetler de bulunmaktadır ${ }^{52}$. Âyetlerin bir kısmı bir kısmının hükmünü kaldırabildił̌i gibi (nâsih) bir kısmının da hükmü zaman içinde kaldırılmı̧ (mensuh), bazı âyetler de mutlak olarak gelen kimi âyetlerin hükmünü sınırlandırarak (takyid) bazı şartlara bağlamıştır. Bu yüzden ileri gelen müfessirler, bazı âyetlerin bazı âyetleri tefsir ettiğ hususunda fikir birliği içindedirler. Bütün bunlardan dolayı tefsir sanatı önemli ve zor bir iş oldugundan müfessirler bu konuda zorlanırlar ${ }^{33}$.

\footnotetext{
${ }^{51}$ Dârü'l-Hilâfe Medreseleri Ders Cetvelleri ve Müfredat Programu, s. 7.

${ }^{52}$ Bu âyetler arasında içkinin yasaklandığı (Nisa 4, 43), vasiyet ile ilgili olan (Bakara 2, 180), zekatla ilgili olan (Tevbe 9,60 ) âyetler örnek olarak verilmektedir.

${ }^{33}$ Dârü'l-Hilâfe Medreseleri Ders Cetvelleri ve Müfredat Programu, s. 85.
} 
Kur'ân'ın Isrâiliyâtla tefsiri hatadu ${ }^{54}$. Bu nedenle tefsir müderrislerinin bu yola gitmeleri çok yanlış olacaktır. Müderrislerin, imkânlar ölçüsünde isrâiliyât ve hurafelere dayanan konuları tenkit etmeleri gerekir. Onun için müderrislerin âyetleri tefsir ederken şunlara riayet etmeleri gerekir ${ }^{55}$ :

1. Kur'ân'da geçen kapalı ve anlaşılması güç olan ifadeler açıklanmalıdır.

2. Âyetlerin indiriliş sebepleri (esbâb-ı nüzul) açıklanmalıdır.

3. Âyetlerin meali verilmekle birlikte, ortaya koydukları emir ve yasaklar itibarıyla amaçları üzerinde de durulacaktır.

4. Bir âyetin amacı izah edilirken bu amaçla bağlantısı ve ilgisi olan diğer âyetlere de yer verilecektir.

Muallimin, dersin yeterince anlaşılabilmesi için tefsir ettiği âyetlerden her birinin nüzulünü gerektiren sebepleri ve nüzul zamanını da incelemesi ve tahlil etmesi gerekir.

5. Müderris, Kur'ân'ın yalnız peygamberin asrının değil her mekan ve zamanda bütün Müslümanların kitabı olduğunu hatırlatmalıdır.

6. Tefsir müderrisleri tedris edecekleri dersleri akıl sahibi insanların düşünüp kabul edemeyeceği yaklaşımlardan uzak tutmalıdır. Bu konulara ait tefsir eserlerinde yer alan ifadeleri - rivayet kabilinden bile olsa - katiyen zikretmeyecektir.

7. Müderris, âyetleri tefsir ederken İslâm düşmanları tarafından bilerek veya bilmeyerek hücum sebebi olan âyetlere gelince, bunlar üzerinde fazlaca durup Kur'ân'ın özü ile bağdaşmayan sözleri tenkit ederek reddetmelidir ${ }^{56}$.

Aynı ögretim basamağında yer verilen Hadis dersinde ise Bülúğ'l Meram fi Ehâdisi'l Ahkâm ${ }^{57}$ adlı eser, bu eser bulunmadığı takdirde Meşârik takip edilecektir. Hadis muallimleri hadis derslerinde takip edilecek yöntem konusunda önceki izaha dikkat edeceklerdir ${ }^{58}$. Her üç sınıfta üçer saat yer verilen Usûl-i Fıkıh dersinde ise şerhi ile birlikte Menâr okunacaktır.

Yine her üç sınıfta üçer saat yer verilen Kelam dersinde ilk sınıfta kelamın konusu, faydası, amacı, clinî hükümler ile bunlara delil teşkil eden kaynaklar, bilgi kaynakları, dinî ilimlerin tasnifi, Kelam ilminin doğuşu ve

${ }^{\$ 4}$ Bu gerçeğin Kur'an'da yer alan "Kitap kendilerine gelince, onlar, onu inkar etmişlerdir; oysa 0 , değerli bir kitaptır. Geçmişte ve gelecekte onu bâtıl kılacak yoktur. Hakim ve övülmeye layık olan Allah Katından indirilmedir" (Fussilet 41,4l-42), âyetinin gereği olduğu ifade edilmektedir.

${ }^{55}$ Dârü'l-Hilâfe Medreseleri Ders Cetvelleri ve Müfredat Programı, s. 85.

${ }^{56}$ Bu konuda (Duha 93, 7), (Hacc 22, 52), (1sra 17, 22), (Ahzab 33, 1 ve 37) âyetleri ömek olarak verilmektedir. Dârü'l-Hilâfe Mıdreseleri Ders Cetvelleri ve Müfredat Programı, s. 88

57 Ibn-i Hacer el-Askalani (v. 852/144'7)'nin ibadet ve muamelat konularına dair sahih hadisleri topladı̆̆ı bir mektep kitabı laacmindeki bu eseri için, Bk. A. Osman Koçkuzu, "Bülûgu'l-Meram", TDV. İlam Ansiklopedisi VI, s. 412.

${ }^{58}$ Dârü'l-Hilâfe Medreseleri Ders Cetvelleri ve Müfredat Programu, s. 88. 
ekoller, bugün var olan kelamî akımlar, Islam Felsefesi, Tasavvuf, tabiat kanunları ve imkânı, madde, hayat ve ruh hakkındaki nazariyeler gibi konulara yer verilecektir. İkinci sınıfta, Allah iman ve Allah'ın varlığı konusunda çeşitli felsefî cereyanlar tarafından ileri sürülen şüphelerin çeşitli delillerle ispat edilerek giderilmesi ve Allah'ın sıfatları konuları işlenecektir. Son sınıfta ise ilâhî sıfat ve fiiller, kaza-kader, kitaplar, melekler, vahyin mümkün oluşu, peygamberlerin görevleri ve sıfatları, mucize ve Kur'an'ın mucize oluşu, İslâm'ın akıl ve düşünmeye verdiği değer, âhiret hayatının aklen mümkün oluşu ve cennet-cehennem konularına yer verilecektir ${ }^{59}$.

Birinci sınıfta üç saatlik yer verilen İlm-i Nefs (Psikoloji) dersi ile üçüncü sınıfta bir saat olarak yer verilen Ahlâk ve yine aynı sınıfta iki saat yer verilen Terbiye ve İlm-i İçtima' dersleri de din eğitimi ve öğretimine yardımcı ve destek niteliğinde dersler olarak değerlendirilmelidir. Ahlâk dersinde daha çok ahlâkın felsefi yapısı üzerinde durulmakla birlikte, insan ve toplum ilişkileri üzerindeki etkisi konularına da yer verilmiştir. Terbiye ve İlm-i İçtima' dersinde eğitimin tanımı, konusu, İslâm'ın eğitime bakışı, eğitimin gücü, öğretim yöntemleri ve ünlü İslâm eğitimcilerinin görüşleri ile sosyolojinin yöntem ve prensiplerine genel olarak yer verilmektedir. İlm-i Nefs (Psikoloji) dersinde ise Naim Bey'in tercüme ettiği İlm-i Nefs adlı kitap takip edilecektir ${ }^{60}$.

\section{5. İhtisas Medresesi (Medresetü'l-Mütehassısîn)}

TABLO 9 : 1922 Yılında Medrese-i Süleymâniye (İhtisas Medresesi) İçin Hazırlanan Program

Tefsir ve Hadjs Sûbesi

DERSLER

Tefsir-i Şerif

Hadis-i Şerif

Usûl-i Hadis ve Nakd-i Ricâl

Tabakât-1 Kurrâ ve Müfessinin

Toplam Saat

$\frac{1 . \text { S InIf }}{4}$
4
2
2
12

Fıkıh ve Usûl-i Fıkıh Sûbesi

\section{DERSLER}

Fikh-ı Hanefî

Fikh-1 Şâfîi

Fıkh-ı Mâlikî

Fıkh-ı Hanbelî

$\frac{1 . S \sin 1 \mathrm{f}}{5}$
2
1
1

$\frac{2 . S_{\text {InIf }}}{4}$
4
2
2
12

$\underline{\text { 3. Sinif }}$

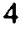

4

2

2

12

${ }^{39}$ Dârü'l-Hilafe Medreseleri Ders Cetvelleri ve Müfredat Programi, s. 90-91.

${ }^{60}$ Dârül-Hilâfe Medreseleri Ders Cetvelleri ve Müfredat Programı, s. 92-93, 102. Bu eser hakkında bilgi clde edilememiştir. 
Usûl-i Fıkıh

Hilâfiyât

Tarih-i Fıkıh

Toplam Saat

$\begin{array}{lll}5 & 5 & 5 \\ 2 & 2 & 2 \\ 2 & 2 & 2 \\ 18 & 18 & 18\end{array}$

$\begin{array}{lll}\frac{1 . S \text { S111 }}{4} & \frac{2 . \text { Sinif }}{4} & \frac{3 . \text { Sinif }}{4} \\ 2 & 2 & 2 \\ 2 & 2 & 2 \\ 2 & 2 & 2 \\ 2 & 2 & 2 \\ 2 & 2 & 2 \\ 2 & 2 & 2 \\ 2 & 2 & 2 \\ 18 & 18 & 18\end{array}$

Kelam ve Hikmet Ŝ́besi

DERSLER

İlm-i Kelâm

Tasavvuf

Felsefe-i Islâmiye Tarihi

Hikmet-i llâhiye

Mantık

Ilm-i Nefs ve Ahlâk

Felsefe-i Umûmiye Tarihi

Tarih-i Edyân ve Din-i İslâm

Toplam Saat

\section{TABLO 10 : 1923 Yılında Dârü't-Hilâfe Medreseleri Medresetü’ Mütehassısîn} (Medrese-i Süleymaniye) İçin Hazırlanan Program

Tefsir ve Hadis Sûbesi

\section{DERSLER}

Tefsir-i Şerif

İlm-i Edyân"*

Tarih-i Din-i İslâm *."

Usûl-i Hadis ve Nakd-i Ricâl

Tabakâtü'l Kurrâ ve'l-Müfessirîn Toplam Saat
Hadis-i Şerif

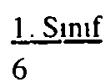

6

2

2

16

Fıkıh ve Usûl-i Fıkıh Sûbesi

\section{DERSLER}

Fikh-1 Hanefi

Fıkh-1 Şâfiî

F1kh-1 Mâlikî

Fıkh-1 Hanbelî

Usûl-i Fıkıh

Hilâfiyât

Tarih-i Fıkıh

Toplam Saat

$\frac{1 . S \ln 1 \mathrm{f}}{5}$
2
1
1
5
2
2
18

\section{$\frac{2 . \operatorname{Sin} 1 \mathrm{f}}{6}$}

6

2

2

16

2

16

.. $\quad$ Birinci sınıfta Tefsir'e nukaddime olmak üzere İlm-i Edyân tedris edilecektir.
... $\quad$ İkinci Sınıfta Hadis'e mukaddime olmak üzere Tarih-i Din-i Islâm tedris edilecektir. 
Kelam ve Hikmet Sûbesi

\begin{tabular}{|c|c|c|c|}
\hline DERSLER & 1. $S_{\ln 1 f}$ & 2. Sinif & $\underline{\text { 3. Sintf }}$ \\
\hline İlm-i Kelâm & 4 & 4 & 4 \\
\hline Tasavvuf & 2 & 2 & 2 \\
\hline Felsefe-i İslâmiye Tarihi & 2 & 2 & 2 \\
\hline Hikmet-i İlâhiye & 2 & 2 & 2 \\
\hline Mantık & 2 & 2 & 2 \\
\hline İlm-i Nefs ve Ahlâk & 2 & 2 & 2 \\
\hline Felsefe-i Umumiye Tarihi & 2 & 2 & 2 \\
\hline Tarih-i Edyân ve Din-i İslâm & 2 & 2 & 2 \\
\hline Toplam Saat & 18 & 18 & 18 \\
\hline
\end{tabular}

Medresenin bu aşamasının Tefsir-Hadis, Fıkıh-Usul-i Fıkıh ve KelamHikmet adlarıyla tam̄amen dînî ilimlerin çeşitli alanlarında ihtisas (uzmanlık) öğretimine ayrıldığı, her iki programda da açıkça görülmektedir. 1923 yılında önceki programın olduğu gibi muhafaza edilerek, sadece Tefsir-Hadis şubesinde Tefsir dersinden önce İlm-i Edyân (Dinler Tarihi), Hadis dersinden önce de Tarih-i Din-i İslâm (İslâm Dini Tarihi) derslerinin okutulacağı ifade edilmektedir. Ön şart olarak programa alınan bu derslerden Dinler Tarihi'nin hatta Mukayeseli Dinler Tarihi'nin Tefsir dersinden önce okutulmasının dinin menşei, din ve toplum ilişkileri, dini inancın farklı toplumlarda tezahür şekillerinin bilinmesi, ayrıca İslâm Dini'nin temel kaynağı olan Kur'ân'ın daha iyi anlaşılması yönlerinden yardımcı olacağı düşünülmüş olmalıdır. Nitekim İslâm'ın temel inanç değeri olan tevhid anlayışının ilk insandan bu yana peygamberler aracılığı ile ulaştırıldığı ve esasen İslâm'ın da bu süreç içindeki son halka olduğu düşüncesi Müslümanlar tarafından benimsenmektedir. Diğer taraftan Kur'ân'da sözü edilen birçok din, inanç ve milletlerden de bahsedilmektedir. Bu durumda, Tefsir öğrenimi gören kimsenin Kur'an'da yer alan inanç, ibadet ve diğer konularla ilgili esasları anlama ve yorumlama konusunda özellikle ilâhî dinler hakkında bilgi sahibi olmasının gerekli olduğu düşüncesindeyiz. Benzer şekilde Hadis dersinden önce Cahiliye ve İslâm'ın ilk dönemlerinin bilinmesinin yanısıra, Hz. Peygamber'in yetiştiği toplumun gelenek ve degerlerinin bilinmesinin hadislerin anlaşılması ve yorumlanmasında son derece önemli olduğu açıktır.

1914 tarihli Islâh-ı Medâris Nizamnamesi ile kuruluşu kararlaştırılan ve 1915 yılında faaliyete geçen Medresetü'I Mütehassısîn'in ilk programı ${ }^{61}$ 1923 yılında hazırlanan ile karşılaştırıldığında bazı değişikliklere uğradığı görülmektedir. Her iki programda da aynı bölümlere yer verilirken isimlerde değişiklikler yapılmıştır. Öncelikle 1915 yılında iki yıl olarak belirlenen öğretim süresi 1923 yılında üç yıla çıkartılmıştır.

${ }^{61}$ Bk. Ceride-i llmiye, 2. Sene, Aded 14, Şaban 1333 (Haziran 1915), s. 90-91; Ilmiye Salnamesi, Matbaa-i Âmire, İstanbul 1334, s. 667. 
Yine 1915 yılında her iki sınıfta derslere ayrılan toplam haftalık süre Tefsir-Hadis Şubesinde $42(21+21)$, diğer iki şubede $48(24+24)$ saat iken, bu sayı 1923 yılında Tefsir-Hadis Şubesinde $48(16+16+16)$, diger iki şubede ise $54(18+18+18)$ saat olarak belirlenmiştir. Diğer taraftan 1915 yılında yer verildiği halde daha sonra kaldırılan dersler bulunmaktadır ki bunlar arasında Tefsir-Hadis Şubesinde Usûl-i Tefsir, Kelam ve Hikmet Şubesinde Mezhepler Tarihi, Sosyoloji (Illm-i İçtima'), Felsefe-i Ûlâ (Ilkçağ Felsefesi) derslerine 1923 programında yer verilmemesini doğru bulmadığımızı belirtmeliyiz. Bunların dışında 1915 yılında Fıkıh ve Kelam-Tasavvuf-Felsefe adlı şube adları 1923 yılında Fikıh ve Usul-i Fikıh ile Kelam ve Hikmet adlarıyla değiştirilmiştir.

\section{B. İlmiye Medreseleri}

TABLO 11 : 1921 Medâris-i İlmiye Nizamnamesi'ne Göre İlmiye Medreselerinin Ders Programı

\begin{tabular}{|c|c|c|c|c|c|c|}
\hline K1sm-1 Evvel & & & & & & \\
\hline DERSLER & 1. Sinif & 2. Sinif & $\underline{\text { 3. Sinif }}$ & 4. Sinif & $\underline{5 . \operatorname{Sinif}}$ & $\frac{6 . \sin 11}{.}$ \\
\hline Tertil-i Kur'an & 4 & - & $\overline{4}^{-}$ & . & . & . \\
\hline Halebî & $\cdot$ & 4 & - & 5 & 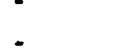 & \\
\hline $\begin{array}{l}\text { Kudûrî } \\
\text { Mülteka (veya lğâse }\end{array}$ & - & • & - & & & \\
\hline Tâlibîn) & - & - & - & - & 5 & 5 \\
\hline Ferâiz & - & - & - & - & $I$ & - \\
\hline Tarih-i İslâm & - & - & - & - & - & 3 \\
\hline Nûniye & - & - & - & - & - & 1 \\
\hline Lügat-i Arabiye & 3 & 2. & - & - & - & - \\
\hline İmlâ ve Kıraat & 2 & 2. & - & - & - & - \\
\hline Hesap & 2 & 2 & 2 & - & - & - \\
\hline Hat & 2 & 2 & - & - & - & - \\
\hline Avâmil ve Izhar & - & 5 & - & - & - & - \\
\hline Sarf & 5 & - & - & - & - & - \\
\hline Arabî & - & 1 & - & - & - & $\cdot$ \\
\hline Molla Câmî & - & - & 5 & 5 & - & - \\
\hline Merah & - & - & 2 & - & - & - \\
\hline Kavâid-i Osmaniye & - & 2 & - & - & - & - \\
\hline Coğrafya & - & - & 2 & 2 & - & - \\
\hline Kıraat-1 Arabiye & $\cdot$ & - & 1 & - & - & - \\
\hline Kavâid ve Kitâbet & - & - & - & 2 & - & $\cdot$ \\
\hline Hendese & - & - & - & 2 & - & - \\
\hline İsagoji vc Alâka & - & - & - & 2 & - & $\bar{s}^{-}$ \\
\hline Mantık & - & - & - & - & 5 & 5 \\
\hline Vaz' & - & - & $\cdot$ & - & 1 & - \\
\hline
\end{tabular}




$\begin{array}{lllllll}\text { Farisî } & - & - & - & - & 2 & - \\ \text { Kitabet veya } & & & & & & \\ \text { Edebiyat-ı Türkiye } & - & - & - & - & 2 & - \\ \begin{array}{l}\text { Tarih-i Osmanî } \\ \text { Adâb }\end{array} & - & - & - & - & 2 & - \\ \text { Gülistan } & - & - & - & - & - & 2 \\ \quad \text { Toplam Saat } & 18 & 18 & 18 & 18 & 18 & 18\end{array}$

\begin{tabular}{|c|c|c|c|c|c|c|}
\hline \multicolumn{7}{|l|}{ KISm-I Sânî } \\
\hline DERSLER & 7. Sinif & 8. Sınıf & 9. $S_{\text {InIf }}$ & 10. Sinif & 11. Sinif & 12. Sinıf \\
\hline \multirow[t]{2}{*}{ Kelam } & 5 & 5 & 5 & 5 & $\cdot$ & -Ferâiz \\
\hline & 2 & - & - & - & - & - \\
\hline Usul-i F $t k t h$ & - & - & 2 & 5 & 5 & - \\
\hline Ahlâk & - & - & 2 & - & - & - \\
\hline Usul-i Hadis & - & - & - & 2 & - & - \\
\hline Medeniyet-i Islâmiye Tarihi & - & - & - & 2 & - & - \\
\hline Tefsir ve Hadis & - & - & - & - & 5 & 5 \\
\hline Durer (Muamelat Kısmı) & - & - & - & - & $\cdot$ & 5 \\
\hline Şifa & - & - & - & $\cdot$ & - & 2 \\
\hline Hifz-1's-Sihha & 1 & - & - & - & - & - \\
\hline Edebiyat-1 Arabiye & - & 2 & - & - & - & - \\
\hline Muhtasar Meânî & 5 & 5 & - & - & - & - \\
\hline Tarih-i Umumî & - & 2 & 2 & - & - & - \\
\hline Mecelle & - & - & - & - & 2 & - \\
\hline Toplam Saat & 13 & 14 & 11 & 14 & 12 & 12 \\
\hline
\end{tabular}

1921 tarihli Medâris-i İlmiye Nizamnamesi'nin hazırlanış gerekçesinde, Anadolu'nun birçok yerinde namaz kıldıracak, cenazeleri kaldıracak ve halkın din hakkındaki sorularına cevap verebilecek din görevlisinin bulunmadığı belirtilerek, söz konusu alandaki ihtiyacın karşılanması gerektiği vurgulanmaktadır. Gerekçede, bu ihtiyacı karşılayacak görevlilerin medreselerden yetiştirileceği; ancak bir taraftan seferberlik dolayısıyla medrese talebesi ve müderrislerin çoğunun silah altına alınması, diğer taraftan da yeni kurulan Dârü'l-Hilâfe Medreseleri'nin yeterince yaygınlaştırılamaması yüzünden din görevlisi ihtiyacının azami derecede arttığı belirtilmektedir. Esas çözüm bu medreselerin yaygınlaştırılması olmakla birlikte; ekonomik şartların elverişsiz olması dolayısıyla, Dârü'lHilâfe Medreseleri teşkilatına alınmayan medreselerden de (medâris-i atîka) bu ihtiyacın karşılanması noktasında faydalanılması zaruret hâlini almıştır. Böylece, program ve idaresi nizamnamede belirlenen esaslar çerçevesinde yeni medreselerin kurulmasındaki başlıca amacın, halkın dinî ihtiyaçlarını karşılayacak imam-hatip ve vaiz gibi görevlilerin yetiştirilmesi olduğu 
belirtilmektedir ${ }^{62}$. Bu amaçla hazıllanan programın Dârü'l-Hilâfe Medreseleri'nden birtakım farklılıklar taşıyacağı baştan belli olmakla birlikte, ortak taraflarının daha yoğun olmasını beklemek herhalde yanlış olmayacaktır.

Öğretim süresi altışar yıllık iki kısımdan oluşan İlmiye medreselerinin ilk kısmı (Kısm-1 Evvel) için hazırlanan programda matematik, fen, Türkçe ve sosyal bilgiler derslerine yer verilmesi itibarıyla Dârü'l-Hilâfe Medreseleri'nin Tâli Kısm-ı Evvel ve Sâni kısımları için hazırlanan program ile benzerlikler taşıdığı görülmektedir. Programda meslek dersleri ile bunun dışında kalan derslerin genel ağırlıklarına bakıldığında da her iki medrese programı arasında önemli benzerlik görünmektedir. Bu kısımda öğretim süresince tedris edilecek 108 saatlik ders süresi içinde din öğretimi ile ilgili alan derslerine $32(\% 30)$, diğer derslere ise $76(\% 70)$ saatlik süre ayrılmıştır. Buna karşılık bu durum ikinci kısımda ters dönerek, alan öğretimine çok daha yoğun olarak yer verilmiştir. Nitekim ikinci kısımdaki öğretim süresince yer verilen 76 saatlik ders süresi içinde alan derslerine 57 (\% 75) alan dışı derslere ise $19(\% 25)$ saatlik ders süresi aynilmıştır ${ }^{63}$.

Bununla birlikte ilk kısımda genel kültür dersleri olarak saydığımız dersler arasında yer alan ve aslında geleneksel medrese programlarında yer verilen Arapça, Farsça ve Mantık ïğretimine ayrılan sürenin 48 saat olduğu ve bunun da oranının $\% 41$ gibi yüksek bir rakam olduğunu belirtmeliyiz. Yine programla ilgili olarak dikkati çeken diğer bir husus da klasik medrese programlarında görülen, derslerin kitap ismi ile zikredilmesi anlayışının burada da devam ettirilmesidir. Halebi ${ }^{64}$, Durer $^{65}, K_{u d u ̂ r} \hat{t}^{66}$ ve Multekâa $\hat{a}^{67}$ gibi

62 “........Medâris-i atîkayı zamana evfak bir surette ihya ve ıslah ederek asri eimme ve ulema ve vaiz yetiştirmek sureti münasip görülmüş ve bu maksatla mesdud kalan müessesat-1 diniyemizin - yümnihi Teala - ez ser ne:v ihya ve küşadına teşebbüs edilerek işbu medârise Medâris-i İlmiye namı verilmiş ve bu hususta ayrıca bir nizamname kaleme alınmıştır”. Bk. "Medâris-i llmiye Nizamnamesi Esbâb-1 Mucibe Lâyihası", Medâris-i llmiye Nizamnamesi, Şehzadebaşı Evkâf-1 İslamiye Matbaası, 1338-1341, s. 3-4.

${ }^{63}$ Programda yer verilen derslerin ağırlıklan Tablo 12' de verilmiştir.

*4 Halebî, el-Kaşgârî (v. 705/1305)'nin Münyetü'l Musallî ve Gunyetü'l Mübtedî adlı Fıkıh eserine İbrahim b. Muhammed Halebî (v. 906/1597-1598)'nin aynı zamanda Halebi-i Kebîr adıyla bilinen Gunyetül Mütemellî Fî Şerh-i Münyetü'l Musallî adlı şerhidir. Eser daha sonra İbrahim Halebî tarafindan Muhtasaru Gunyetüll Mütemellî Fî Şerh-i' Münyetü'l Musallî adıyla kısaltılmış ve Halebi-i Sağîr adıyla meşhur olmuştur. Bk. Kâtip Çelebi, Keşü'z Zünûn II, MEB Yay., İstanbul 1943, s.1886-1887; Halebi-i Sağir, İstanbul 1303 (1886). Eser, Babadağî tarafından Türkçe'ye çevrilerek $1255 / 1839$ yılında basılmıştır. Bk. Halebi-i Săgir r, Dârü't Tabaâtü't Âmire, İstanbul 1255.

${ }^{65}$ Tam adı Dürerü'l Hükkâm fí Şerh-i Gureri'l Ahkâmı olan bu eser Molla Husrev (v. 885/1480)'in Gurerül Ahkâm adlı Fikıh'a dair eserine yine kendisi tarafından yapılan şerhtir. Bk. Kâtip Çelebi, Keşü'z Zünûn II, s. 1199-1120. 
Fıkıh eserlerinin yanısıra Alâka ${ }^{68}$, Avâmil, Izhar, Merah, Molla Câmi, Arap dili, Nûniye $e^{69}$ Akaid, Gülistan, Farsça, İsagojii ${ }^{70}$ Mantık, Şifẩ $\hat{a}^{71}$ Siyer ile ilgili eserlerdir ve programa bu isimlerle alınmışlardır. Bu yönleri göz önüne alındığında, programın geleneksel medrese programından çok fazla farkının olmadığ 1 rahatlıkla ileri sürülebilir.

Programa genel olarak bakıldığında ilk kısımda yer verilen meslek dersleri içinde Kur'ân ve Akaid derslerinin ağırlığının oldukça az olduğu görülmektedir. Kur'ân dersine bütün öğretim süresi boyunca ilk sınıfta haftada dört saat olarak yer verilmiştir. Diğer taraftan Fıkıh derslerinde, ders kitabı niteliği taşımayan, Arapça olarak kaleme alınmış Halebî, Kudûrî ve Multekâ gibi eserlerin yerine Dârï'l-Hilâfe Medreselerinde okutulan, iman ve ibadet konuları belirli bir düzen içinde kaleme alınmış Türkçe eserlerin okutulmasının öğretim hedeflerine ulaşılması açısından daha doğru olacağı ileri sürülebilir.

İlmiye Medreseleri'nde Dârü'l-Hilâfe Medreseleri'nde olduğu gibi, okutulan dersler için içerik hazırlanmadığına bakılarak, belirtilen kitapların içeriğini aynı zamanda ilgili dersin içeriği olarak da kabul etmek gerekir. Bu

${ }^{66}$ Ahmet b. Cafer el Kudûrî (362-428/972-1037)'nin el-Muhtasar adlı eseridir. Eserin Türkçe tercümesi için, Bk. Kayıtlı Kuduri ve Tercemesi, Çeviren : Ali Arslan, Salah Bilici Kitabevi, Istanbul 1968.

67 Ibrahim b. Muhammed Halcbî (v. 906/1597-1598)'nin Fıkıh'a dair Mültekâ'l Ebhûr adlı eseridir. Bk. Kâtip Çelebi, Keşfü'z Zünûn. II, s. 1814. Medreselerde yaygın olarak okutulan bu kitap için, Bk. Multeka'l Ebhur, Darü't Tabaatü'l Âmire, İstanbul 1274 (1858). Escrin sadeleştirilmiş tercümesi için, Bk. Muhammed Mevkufati, Mülteka Tercümesi I-IV, Sadcleştiren : Ahmed Davudoğlu, Sağlam Yayınevi, İstanbul (tarihsiz).

68 Alâka, kelime olarak bir kelimenin gerçek anlamından mecâzî anlamına nakledilmesi yani edebî bir sanat olarak istiâre demektir. Kaynaklara Risaletü'l I stiâre adıyla bakıldığında bu adla birçok escrin olduğu görülmektedir. Bunlar arasında Ebu'l Leys Semerkandî‘nin, Bk. Kâtip Çelebi, Kesfü'z Zünûn, I, s. 845, Mahmut b. Abdullah Antâkî'nin, Bk. Bağdatlı İsmail Paşa, Izâhu'l Meknûn Fi Zeyl-i Ala Keş̧i'z Zünûn An Esamii'l Kütüb ve'l Fünun, I, İstanbul 1947, s. 557, ve Gözübüyük-zâde İbrahim Efendi'nin Risaletü'l İstiâre adını taşıyan eserleri zikredilebilir; ancak bu cserlerden hangisinin okunduğuna dair bilgi bulunmamaktadır.

${ }^{69}$ Hizır Bey'in (v. 863/1458-1459) tam adı Kaside-i Nûniye olan manzum eseridir. Eserin metni ve Türkçe tercümesi için, Bk. M. Sait Yazıcıoğlu, "Hızır Bey ve Kaside-i Nûniye'si", AÜIF Dergisi XXVI, Ankara 1983, s. 549-588.

${ }^{\pi}$ Esirüddin Mufaddal b. Ömer El-Ebherî (v. 663/1265)'nin Mantığa dair eseridir. Bk. H. Ragıp Atademir, "Porphyrios ve Ebherî"nin Isagoci'leri", AÜDTF Dergisi VI, Sayı:5, Kasım-Aralık 1948, s. 461-468; Abdülkuddüs Bingöl, "Ebherî Esirüddin”, TDV. Islâm Ansiklopedisi, X, İstanbul 1994, s. 76. Osmanlı medreselcrinde son dönemlere kadar okutulan bu eserin birçok şerhi bulunmaktadır.

"Es-Sifâ bi Târîf-i Hukûki'l-Mustafa adlı Hz. Peygamber'in hayatına ait bu eser Kadı lyaz (v. 544/1246-1247)'a aittir. Bk. Kâtip Çelebi, Keşü'z Zünûn, II, s. 1052-1055. 
durumda, söz konusu kitapların içeriklerinin incelenmesi, 1921 tarihli nizamnamenin gerekçesinde belirtilen amaçlara ulaşabilme konusunda ne kadar yeterli olabilecekleri hususunda belirli bir fikre sahip olmamıa yardımcı olacaktır. XVI. asırda kaleme alınarak uzun yıllar hem ilmihal hem de kadılar için bir başvuru kaynağ olma özelliklerini taşıyan $^{72}$ Multeka'l Ebhûr adlı eserde temizlik, namaz, hac, oruç, zekat, kurban gibi ibadetlerin yanında evlenme-boşanma, miras (ferâiz), köle ve cariyelerle ilgili hükümler, yeminler, cezalar (hudûd), ganimetler, ticaret ve bununla ilgili kaideler gibi konulara ayrıntılı biçimde yer verilmektedir. Bunlar arasında ibadetlerle ilgili konuların öğrencilere faydalı olacağı açıktır. Hatta o yıllarda yeni medenî kanunun henüz yürürlükte olmadığına bakarak - her ne kadar medresenin kadı yetiştirmek gibi bir amacı yok ise de - yeminler, evlenme, boşanma ve miras gibi hukukî konuların okutulması halka dinî problemlerinin çözümünde yardımcı olmak adına doğru görülebilir. Buna karşıllı cezalar, ticaret, ortaklık vs. gibi o yıllarda geçerliliği hukuken söz konusu olmayan hükümlerin öğretiminin gerekliliği, ancak talebelerin Islâm Hukuku hakkında genel mahiyette bilgi sahibi olmaları amacıyla izah edilebilir. Köle ve cariyeler konusu için böyle bir izah yapabilmek ise mümkün değildir. Eserde inançla ilgili konulara yer verilmemektedir. Aynı özellikler Halebi, Durer ve Kudûri için de geçerlidir. Bu eserlerin gereksiz ve değersiz olduklarını ileri sürebilmek mümkün değildir; ancak söz konusu ettiğimiz dönemdeki programda gerçekleştirilmesi öngörülen amaçlara ulaşma noktasında isabetli oldukları düşüncesinde değiliz. Hatta geleneksel medrese programının tenkit edilerek yetersiz kaldığı düşüncesinin öne çıktığı ve bunun giderilmesi için ciddî çalışmaların yapıldı̆̆ı bir dönemde hazırlanan programda böyle bir yaklaşımın sergilenmesinin bir tezat olduğu da ileri sürülebilir.

Yine, iman ve ibadet konularının öğretiminde öncelik iman ve itikatla ilgili konulara verilseydi herhalde daha doğru olurdu. Halbuki ilk kısımda ibadet konularına geniş yer verilen Fıkıh dersleri yoğunlaşırken inanç konularının işlendiği Kaside-i Nûniye adlı kitabın okutulmasına ancak altıncı sınıfta ve bir saat olarak yer verilmiş, yine itikat konularının yer aldığı Kelam derslerine de ikinci kısımda ağırlık verilmiştir. Içerdiği soyut konular itibarıyla Kelam öğretimine ikinci basamakta yer verilmesi, 12 yaşından ${ }^{73}$ itibaren medreseye kabul edilen talebelerin hem öğrenme hem de gelişim seviyeleri dikkate alındığında yerinde bir uygulama olmakla birlikte bu gelişim seviyesine uygun seviyede inanç konularının işlenmesi gerektiğini de gözden uzak tutmamak gerekir. Altıncı sınıfta okutulan söz konusu eserin

${ }^{72}$ Has, "The Use of Multaqa'l-Abhur in The Ottoman Madrasas in Legal Scholarship", Osmanlı Araştırmaları (The Journal of Ottoman Studies) VII-VIII, Istanbul 1998, s. 398 399.

73 “Medâris-i tlmiye Nizamnamesi", mad. 9. 
bu konuda öğrencilerin gelişim seviyesine uygun bir seçim olmadığı düşüncesindeyiz.

Meslek dersleri dışında değerlendirdiğimiz Türkçe ve sosyal bilgiler derslerine yeterli ağırlık verilmediği gibi Sosyoloji ve eğitim derslerine ise hiç yer verilmemektedir. Halbuki din görevlisi olacak kişilerin bu konularda bilgiye ihtiyacının olacağı açıktır.

Diğer taraftan kanaatimizce din görevlisine yoğun ihtiyacın olduğu gerekçesi ile başlatılan bir çalışmanın 12 yıllık bir öğretim süresi ile planlanmasını diğer bir tutarsızlık olarak değerlendirmek gerekir. Çünkü Dârü'l-Hilâfe Medreseleri'nde köy veya şehirlerinde imamlık yapabilecek olanlar 5 veya 8 yılda mezun olabilirken bunun dışında 12 yıllık başka bir programın hazırlanması tutarlı görülmemektedir.

TABLO 12 : 1921 Medâris-i İlmiye Nizamnamesi'ne Göre İlmiye Medreselerinin Programında Yer Alan Derslerin Öğretim Alanlarına Gruplandırılması ve Ağırlıkları

\section{KIsm-1 Evvel}

\begin{tabular}{|c|c|c|c|c|c|c|}
\hline DERSLER & 1. Sınıf & 2. Sinıf & 3. $S_{\text {InIf }}$ & 4. Sinif & 5. Sınıf & 6. Sinif \\
\hline Tertil-i Kur'ân (4 ders \%4) & 4 & - & - & - & - &. \\
\hline \multicolumn{7}{|l|}{ Akaid-Kelam(l ders \%l) } \\
\hline Nûniye & - & - & - & - & - & 1 \\
\hline \multicolumn{7}{|l|}{ Flkıh(24 ders \%22) } \\
\hline$\overline{\text { Ferâiz }}$ & - & - & - & - & $I$ & - \\
\hline Halebi & - & 4 & 4 & - & - & - \\
\hline Kudûrî́ & - & - & - & 5 & - & - \\
\hline \multicolumn{7}{|l|}{ Mülteka (veya } \\
\hline Iğâsetü't Tâlibîn) & - & - & - & - & 5 & 5 \\
\hline \multicolumn{7}{|l|}{ Arapça (30ders \%28) } \\
\hline Arabî & - & 1 & - & - & - & - \\
\hline Avâmil ve Izhar & - & 5 & - & - & - & - \\
\hline Kiraat-1 Arabiye & - & - & 1 & - & - & - \\
\hline Lügat-i Arabiye & 3 & 2 & - & - & - & - \\
\hline Merah & - & - & 2 & - & - & - \\
\hline Molla Câmî & - & - & 5 & 5 & - & - \\
\hline Sarf & 5 & - & - & - & - & - \\
\hline Vaz' & - & - & - & - & 1 & - \\
\hline \multicolumn{7}{|l|}{ Farsça (4 ders \% 4) } \\
\hline Farisî & - & - & - & - & 2 & - \\
\hline Gülistan & - & - & - & - & - & 2 \\
\hline \multicolumn{7}{|l|}{ Mantık(14 ders \% 13)) } \\
\hline Adâb & - & - & - & - & - & 2 \\
\hline İsagoji ve Alâka & - & - & - & 2 & - & - \\
\hline Mantık & - & - & - & - & 5 & 5 \\
\hline
\end{tabular}


Türkce(14 ders \%13)

Hat 2

Imla ve Kıraat

Kavâid ve Kitâbet

Kavâid-i Osmaniye

Kitabet veya Edebiyat-1

Türkiye

Fen Bilgisi ve Matematik ( 8 ders \% 7)

Hendese

Hesap

2

Sosyal Bilgiler( 9 ders \% 8$)$

Coğrafya

Tarih-i İslâm

Tarih-i Osmânî

KIsm-I Sanî

DERSLER

7. Sinif

8. Sinıf 9.Sinif 10. Sinıf 11. Sinif 12. Sinıf

Eikıh (21 ders \% 27)

Durer (Muamelat Kısmi)

Ferâiz

Mecelle

Usul-i Fıkıh

Ahlakk(2 ders \% 3$)$

Tefsir-Hadis(12 ders \% 16)

Tefsir ve Hadis

Usul-i Hadis

Siver-Tarih 8 ders \% 11$)$

Medeniyet-i İslamiye

Tarihi

Şifa

Tarih-i Umumi

Kelam (20 ders \% 26)

Arapca(12ders \% 16)

Edebiyat-1 Arabiye

Muhtasar Meânî

2

2

H1fz-1's-Sihha (1 ders \% 1)

\section{Medresetï'l İrşad}

Medresetü'l Vâizin ile Medresetü'l Eimme ve'l Hutebâ'nın 1919 yılında birleştirilerek Vâizîn (vâizler) ve Eimme ve'l Hutebâ (imam ve 
hatipler)olmak üzere iki şube halinde oluşturulan bu müessese ${ }^{74}$ hakkında 1921 tarihli Medâris-i llmiye Nizamnamesi'nde herhangi bir hüküm bulunmamakla birlikte 1923 yılında Dârü'l-Hilâfe Medreseleri için hazırlanan program ve ders içeriklerinin yer aldığı kitabın son tarafında sadece programına yer verilmiştir ${ }^{75}$.

\section{TABLO 13 : 1923 Medresetü’l İrşad'ın Vâizin Şubesi İçin Hazırlanan Program}

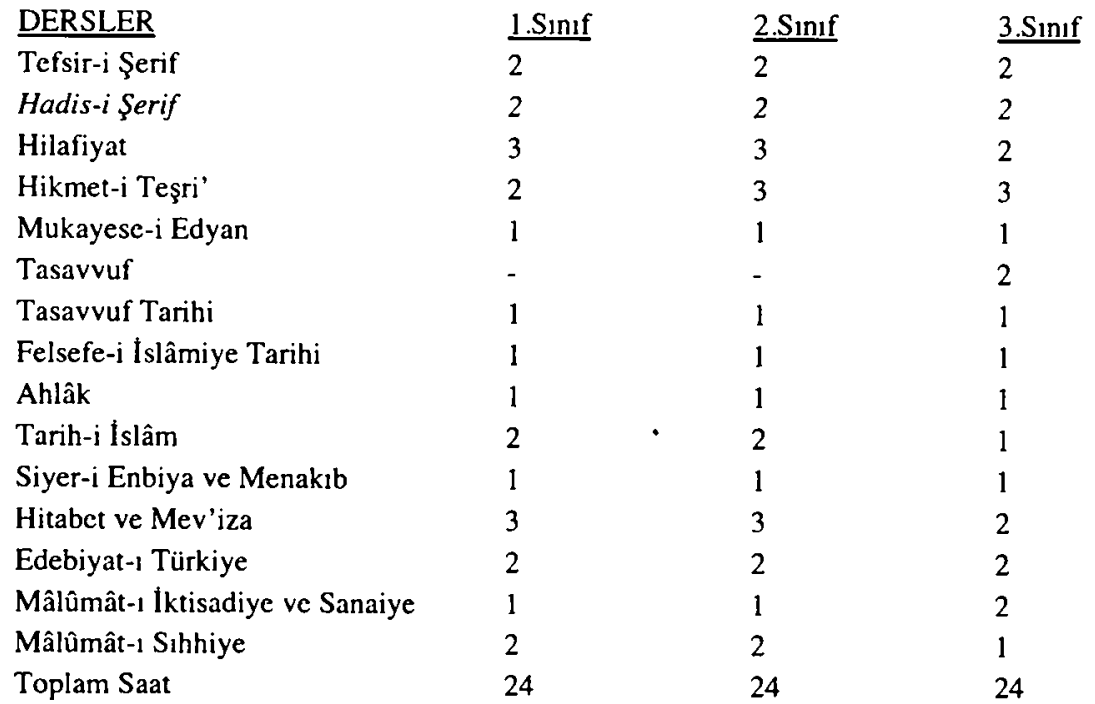

TABLO 14 : 1923 Medresetü’l İrşad'ın Eimme ve'l Hutebâ Şubesi İçin Hazırlanan Program

$\begin{array}{ll}\text { DERSLER } & \frac{1 . S \text { Inıf }}{\text { K. Kerim ve Tecvid }} \\ \text { Vücuh } & 5 \\ \text { Fıkıh (İbadat-Münakehat-Müfarekat) } & 2 \\ \text { Tevhid } & 2 \\ \text { Hitabet } & 2 \\ \text { Mâlûmât-ı Kanuniye } & 2 \\ \text { Kitabet } & 2 \\ \text { Ezan-1 Muhammedi, Mevlid-i Nebi ve Musıki } & 5 \\ \text { Mâlûmât-ı Sıhhiye } & 2 \\ \text { Toplam Saat } & 24\end{array}$

\footnotetext{
${ }^{74}$ Recai Doğan, "II. Meşrutiyet Dönemi Eğitim Hareketlerinde Din Eğitimi-Öğretimi”, $A U ̈ I F$ Dergisi XXXVIII, Ankara 1998, s. 424-429.

75 Dârü'l-Hilâfe Medreseleri Ders Cetvelleri ve Müfredat Programi, s. 119-120.
} 
Vâizîn şubesi için hazırlanan program daha önce Medresetü'l Vâizîn'de uygulanmak üzere 1915 ve 1919 yıllarında hazırlanan programlar ${ }^{76}$ ile karşılaştırılınca yeni programda Fıkıh, Usul-ı Fıkıh, Kelam, Osmanlı Tarihi, Umumi Tarih, Riyâziyat, Tabiiyât, Terbiye-i Bedeniye, Coğrafya, Arapça, Farsça gibi derslerin kaldırıldı $\breve{g}_{1}$ dikkati çekmektedir. Yer verilen derslerin içeriklerinden söz edilmemekle birlikte son programın vâizlik görevinin amaçlarını gerçekleştirmeye daha uygun olduğu, programın genel medrese programından özel alana doğru daha da yoğunlaştığı görülmektedir.

Eimme ve'l Hutebâ kısmında ise daha önce iki yıl olan öğretim süresinin bir yıla indirildiği, Fıkıh, Tefsir, Ahlâk ve Türkçe derslerinin ise kaldırıldığı görülmektedir ki hem öğretim süresi hem de derslerdeki bu değişikliğin imam-hatiplik görevi açısından yetersizlik ve eksiklikler doğuracağı kanaatindeyiz.

1923 yılında Şer'iye Vekâleti Tedrisat Müdür-i Umûmîliği görevinde bulunan Ahmet Hamdi Efendi'nin bu medrese hakkında hazırladığı bir raporu bulunmaktadır ${ }^{77}$. Raporda, medresenin mevcut durumu hakkında bilgi verilerek, daha verimli hâle getirilebilmesi için alınması gerekli tedbirlerden bahsedilmektedir. Buna göre, Medresetü'l Vâizin 1913 yilında ilk açıldığında 150 talebe kabul edildiği hâlde bunların büyük kısmının henüz tahsillerini tamamlayamadan I. Cihan Harbi'nde şehit olmaları yüzünden medrese bir yıl kapalı kalmıştır. Raporda ayrıca medreseden bugüne kadar 40 talebenin mezun olduğu, bunlardan ancak yedi-sekiz kadarına görev verildiği, diğerlerinin ise sefalet ve perişanlık içine düştükleri, bu yüzden de medreseye rağbetin azaldığı, Hutebâ ve Eimme Şûbesi'nin ise neredeyse kapanacak hâle geldiği ifade edilmektedir. Ahmet Hamdi Efendi, bu kurumun istenilen seviyeye gelebilmesi için öncelikle maddî sıkıntıdan kurtarılması ve programının amacına göre yeniden düzenlenmesi gerektiğini belirtmektedir. Hâlen Istanbul'da bulunan medresenin Anadolu'nun önemli bir merkezine taşınması gerektiğini söyleyen Ahmet Hamdi Efendi, Vâizler Şûbesi'ne yüksek dereceli medrese mezunlarından her yıl imtihanla 20 , Eimme ve Hutebâ Şûbesi'ne ise 10 talebenin kabul edilmesi gerektiğini ifade etmektedir. Yine o, buradan mezun olan vâizlerin, İstanbul'daki büyük camilerden ziyade Anadolu'da, imam ve hatiplerin ise kendi memleketlerinde görevlendirilmelerinin daha doğru olacağını, ayrıca bu görevlilere hizmetlerine göre yeterli maaşın da verilmesi gerektiğini belirtmektedir. Programın hazırlanmasından önce kaleme alınan bu raporun özellikle Vâizler Şubesi'nin programının amaca hizmet noktasında yeniden düzenlenmesinde katkısının olduğu anlaşılmaktadır.

${ }^{76}$ Bk. Ceride-i Ilmiye, 1. Sene, Aded : 9, Rebiulevvel 1333 (Ocak 1915), s. 573-576; Ceride-i Ilmiye, 5. Sene, Aded : 51, Rebiulevvel 1338 (Kasım 1919), s. 1239.

$\pi$ Bk. Ahmet Hamdi, "Medresetü'l İrşâd", Sebilürreşad, Aded : 538-539, 6 Zilkade 1341/21 Haziran 1339 (21 Haziran 1923), s. 142-144. 


\section{Sonuç}

1921 yılında hazırlanan ve ilgâ edildikleri tarihten önce yapılan son düzenleme olan Medaris-i Illmiye Nizamnamesi, medreselerin 1914 yılından itibaren ciddî ve köklü biçimde başlatılan idarî yapı ve öğretim programlarını geliştirme çalışmalarının devamı niteliğgindedir. 1914 yılında başlatılan çalışmalarda örnek medrese tipi olarak belirlenen Dârü'l-Hilâfe Medreseleri, İstanbul ile sınırlı tutulmuş, taşrada ise ögretim süresi ve programı daha farklı bir modeli yaygınlaştırılmaya çalışılmıştır. Halbuki 1921 yılında TBMM tarafından başlatılan ve 1922 yılında gerçekleştirilen çalışmalarla, İstanbul ile sınırlı tutulan orta, yüksek ve ihtisas öğretimi aşamalarına sahip Dârü'l-Hilâfe Medreseleri'nin Anadolu'da yaygınlaştırılması esas hedef olarak belirlenmiştir. Bununla birlikte belirlenen hedefin gerçekleştirilmesi imkânının, yaşanılan olağanüstü şartlar dolayısıyla kısıtlı olması gerçeği, daha önceki çalı̧̧malarda göz ardı edilen eski tip medreselerden faydalanma mecburiyetini de doğurmuştur. 1921 tarihli Medâris-i İlmiye Nizamnamesi'nin asıl hedefi, o zamana kadar kendi hâlinde bırakılan bu medreselerin "şimdilik" ve "geçici" olmak kaydıyla belirli bir düzene sokulması çabasıdır.

Yapılan çalışmaların sadece medrese teşkilatı ve idaresi ile sınırlı tutulmayıp program geliştirme ve programlarda yer verilen derslerin içeriklerinin belirlenmesi amacını da taşıdıkları görülmektedir. Dârü'l-Hilâfe Medreseleri için yapılan program geliştirme çalışmalarında, programların ihtiyaç ve amaçlara göre yeniden gözden geçirilip düzenlenmesi esasının uygulandığı ileri sürülebilir. Bu çerçevede söz konusu öğretim kurumlarının amaci; öncelikle imam-hatip, vaiz, müftü veya bu görevlilerin bağlı olduğu teşkilatlardaki memuriyetlerin yanında medreselerde görevlendirilecek idareci ve müderrislerle ilk ve orta dereceli mekteplerdeki din derslerini okutacak muallimlerin yetiştirilmesi olarak belirlenmiştir. Bunun ötesinde din bilimleri alanında akademik çalışmalar yapmak gibi bir amacın, tesbit edebildiğimiz belgelerde açıkça ifadesine rastlamadık. Çeşitli öğretim basamaklarına ayrılan medrese için hazırlanan programlar ile belirtilen amaçlar arasında tutarlıı̆̆ın sağlanmaya çalışıldığı, bu hususta ciddî bir gayretin varlığ

Programların, yetiştirilmesi hedeflenen görevlilerin hizmet alanları dikkate alınarak farklılaştırılması hususunda II. Meşrutiyet yıllarında başlatılan vâiz ve imam-hatip yetiştirmek için ayrı programların uygulanması çalışmalarının yeterince geliştirilerek uygulamaya konulmasında başarı sağlanamadığı anlaşılmaktadır. Bu konunun günümüzde yüksek öğretim kurumlarında gerçekleştirilen din eğitimi için hâlen bir problem olarak devam ettiğini söylememiz mümkündür. Her ne kadar ilk öğretim okullarındaki din derslerinin öğretimini gerçekleştirecek öğretmenlerin yetiştirilmesi ayrı bir yapılanma ile gerçekleştirilmiş olsa da orta öğretim okullarında görevlendirilen din dersi öğretmenleri ile müftü, vaiz gibi din görevlilerinin yetiştirildiği programların yeterliliği yanısıra, birbirlerinden 
ayrılmaları gerekliliği günümüzde de bir tartı̧̧ma konusu olmaya devam etmektedir.

Medreselerin orta kısımları için hazırlanan programlarda ağırlığın genel kültür, sonraki aşamalarında ise alan derslerine ağırlık verildiği, böylece öğretim seviyesi yükseldikçe alan öğretimine verilen ağırlığın da arttığı görülmektedir. Böyle bir yaklaşımın iki amacı olabilir: İlki medrese ile mektep arasında, eğitim-öğretimin genel hedefleri ve öğretim seviyesi arasında paralellik kurulmaya çalışılması; diğeri ise medresenin asıl amacı olan meslek derslerinin öğretiminden önce öğrencilere bu derslerin anlamını daha iyi kavrama ve meslekî anlamda daha iyi kullanabilmeleri imkânının sağlanması çabası. İlmiye medreseleri için hazırlanan programın ise geleneksel medrese anlayışının dışına çıkamadığı görülmektedir.

Diğer taraftan, her seviyedeki programlarda yer verilen derslerin çeşidinin ve haftalık kredi saatlerinin çok yüksek tutulmadığı, böylece hem öğrencilerin farklı alanlar içinde zihinlerinin dağılmasının önlendiği hem de ders dışı faaliyetler için zaman bırakıldığı görülmektedir. Bu durumun, yukarıda sözünü ettiğimiz öğretim seviyesinin yükselmesine paralel olarak alan öğretimine ağırlık verilmesi yaklaşımı ile birlikte ele alındığında, özellikle meslekî ve yüksek öğretimde, hedeflere ulaşabilme hususunda günümüz için de geçerli olan son derece önemli bir konu olduğunu belirtmeliyiz. Bu hususta günümüzdeki uygulamalar göz önüne alındığında programlarda, eskiye oranla pedagojik açıdan bir gelişmenin sağlandı̆̆ı iddiasının zor olduğu, bu konuda yapılan tenkitlerin büyük oranda haklılık paylarının olduğu rahatlıkla ileri sürülebilir ${ }^{78}$. Diğer taraftan özellikle yüksek dereceli medresede, ögretmenlik bilgisi yanısıra insanın ve toplumun daha yakından tanınması için mutlaka gerekli olan bilimlere yer verilmemesi de önemli bir eksiklik olarak kabul edilmelidir.

${ }^{78}$ Günümüzde din eğitimi ve öğretiminin yapıldığı. din görcvlilerinin yanısıra din bilgisi öğretmenlerinin de yetiştirildiği yüksek seviyedeki öğretim kurumlarının öğretim programlanında yer verilen alan ve alan dışı derslerin ağırlıklan, çeşitleri ve haftalık ders saatinin yoğunluğu ile bu hususta yapılan çalışmalar hakkında bilgi ve değerlendirmeler için, Bk. M. Şcrki Aydın, Cumhuriyet Döneminde Din Ĕgitimi Öğretmeni Yetiştirme ve istihdam (1923-1998), Kayscri 2000, s. 136-148. 